\title{
Constraining pre-eruptive magma conditions and unrest timescales during the Monte Nuovo eruption (1538 AD; Campi Flegrei, Southern Italy): integrating textural and CSD results from experimental and natural trachy-phonolites
}

\author{
Fabio Arzilli ${ }^{1,2}$ - Monica Piochi ${ }^{3}$ - Angela Mormone ${ }^{3}$. \\ Claudia Agostini ${ }^{2} \cdot$ Michael R. Carroll $^{2}$
}

Received: 10 December 2015 / Accepted: 3 September 2016/Published online: 24 September 2016

(C) The Author(s) 2016. This article is published with open access at Springerlink.com

\begin{abstract}
We present crystallization experiments representing a broad range of growth conditions of alkali feldspar and sodalite in a trachy-phonolite magma composition during later stages of evolution. Our results include (i) textural data and mineral assemblages of synthetic samples; (ii) feldspar nucleation kinetics and growth rate estimates; and (iii) textural data, mineral abundances, and crystal size distribution measurements on samples representative of the Monte Nuovo eruption (1538 AD), the last eruption of Campi Flegrei, Southern Italy. Experiments reproduced the texture and feldspar content of natural products indicating that kinetic data can provide insights into processes within the volcanic system shortly before and during this small-magnitude eruption and, particularly, about magma ascent timescale. We suggest that the groundmass crystallization of Monte Nuovo magma started between 4 and $7 \mathrm{~km}$ depth $(\sim 100-200 \mathrm{MPa})$ at a temperature between 825 and $840{ }^{\circ} \mathrm{C}$ (close to the liquidus of alkali feldspar). The crystallization kinetics of alkali feldspar and the absence of sodalite in most of the natural samples indicate that magma ascent rate increased in the shallow part of the conduit from about $3 \mathrm{~km}$ depth to the quenching level (possibly fragmentation point; $\sim 30 \mathrm{MPa}$ ), during the first phases of the eruption.
\end{abstract}

Editorial responsibility: P. Wallace

Fabio Arzilli

arzilli.fabio@gmail.com

1 School of Earth and Environmental Sciences, The University of Manchester, Oxford Road, Manchester M13 9PL, UK

2 School of Science and Technology-Geology Division, University of Camerino, Via Gentile III da Varano, 62032 Camerino, Italy

3 Istituto Nazionale di Geofisica e Vulcanologia, sezione Osservatorio Vesuviano, Via Diocleziano 328, 80124 Naples, Italy
The crystallization time of the magma requires that it ascended from pre-eruptive storage to the quenching level in several hours to a few days. We also observe that a small decrease in pressure can induce a dramatic increase in crystallinity, with associated rheological changes, leading to changes in the eruption style, and such changes could occur on timescales of hours to several days. The products from the later phases of the Monte Nuovo eruption are more crystalline and contain sodalite in response to the decrease in magma ascent rate, which in turn allowed for more degassing during ascent, resulting in more time spent at very shallow depths.

Keywords Alkali feldspars · Trachytic melts · Crystallization kinetics $\cdot$ CSD $\cdot$ Monte Nuovo $\cdot$ Campi Flegrei

\section{Introduction}

\section{The aim of the study}

Alkali feldspar is an abundant phase in evolved alkaline rocks (phonolites, trachytes) and is widespread in Campania Province magmas (e.g., Piochi et al. 2005). Its occurrence as microlites in pumice and scoria provides potential information on the timescale of magma migration within the crust, specifically from the magma chamber to the fragmentation level (Marsh 1988; Cashman and Marsh 1988; Marsh 1998). This information may be unraveled by studying the size distribution of microlites pre- and syn-eruptively crystallized and quenched in the matrix of juvenile magma fragments. The crystals present in an igneous rock and the observed variations in both their composition and texture reflect the integrated pressure $(P)$-temperature $(T)$-composition $(X)$-time $(t)$ history of the magma from which they formed. As a result, it is 
possible to link textural observations on rocks with experimentally derived data for rates of crystal growth $\left(Y_{\mathrm{L}}\right)$ and crystal number density $\left(N_{\mathrm{a}}\right)$ for specific mineral phases and the undercooling $(\Delta T)$ values of the parental melt. This approach makes it possible to obtain information on magmatic processes and their timescales using textural observation and growth rates of crystals (Cashman and Marsh 1988; Brugger and Hammer 2010a; Eberl et al. 2002).

However, there are few studies about crystallization kinetics on trachy-phonolitic melts (e.g., Iezzi et al. 2008; Arzilli and Carroll 2013). In this study, we present results for 16 new crystallization experiments on hydrous trachytic melt. These data complement the previous experimental work of Arzilli and Carroll (2013) on the same starting composition. We performed isobaric cooling, isothermal decompression and decompression + cooling experiments, investigating experimental durations and $\mathrm{P}-\mathrm{T}$ conditions not already investigated by Arzilli and Carroll (2013). All of the experiments use the single-step method to reproduce the trachytic melt evolution in response to an instantaneously applied thermodynamic driving force (i.e., undercooling, $\left.\Delta T=T_{\text {liquidus }}-T_{\text {experimental }}\right)$. In our work, we have not attempted to distinguish between the effects of undercooling $(\Delta T)$ at constant pressure and effective undercooling $\left(\Delta T_{\text {eff }}\right)$, which is caused by decompression at constant temperature (Hammer and Rutherford 2002), because it has been shown by Shea and Hammer (2013) and Arzilli and Carroll (2013) that under the same final temperature and pressure, both processes appear to produce similar nucleation and growth rates. Furthermore, we performed decompression + cooling experiments, in which it is difficult to separate $\Delta T$ and $\Delta T_{\text {eff. }}$ Adiabatic cooling during magma ascent could be important, but the magnitude of this effect could be partially counteracted by the release of latent heat from crystallization (La Spina et al. 2015). Decompression + cooling experiments were performed with the goal of studying the crystallization of magma resulting from degassing and adiabatic cooling during ascent. The decompression + cooling experiments also allowed us to investigate several final pressures and undercoolings that could not be studied by simple isothermal decompression.

The experiments were conducted at different pressures and $\Delta T$ values to highlight the differences in crystallinity between high and low pressure (and thus melt $\mathrm{H}_{2} \mathrm{O}$ content). The preliminary study of Arzilli and Carroll (2013) focused mainly on the influence of $\Delta T$ and time on the nucleation and growth of alkali feldspar. They showed the occurrence of several nucleation events of alkali feldspar in short times (hours), with dominance of nucleation at large $\Delta T$. Here we utilize our new experiments and those performed by Arzilli and Carroll (2013) to investigate how crystallization may change as a function of $P_{\mathrm{H}_{2} \mathrm{O}}$ (proportional to melt water content for the watersaturated conditions investigated) and $\Delta T$ (induced by cooling and/or decompression). Our study is focused on understanding how fast the crystallinity of a trachytic magma could change after small variation of pressure. These experiments provide constraints on the $\mathrm{P}-\mathrm{T}$ conditions of trachytic to phonolitic melts during their ascent to the surface, and we use the results to make interpretations about volcanological and magmatic processes during the Monte Nuovo eruption (1538 AD) in the Campi Flegrei (Southern Italy; Fig. 1).

The Monte Nuovo eruption is particularly interesting because it occurred after 3000 years of volcanic quiescence and following a period of ground level movements and seismicity (as described in historical chronicles; Guidoboni and Ciuccarelli 2011) that have characteristics comparable to the recent bradyseisms in the Campi Flegrei area (Parascandola 1947; Del Gaudio et al. 2010). Constraining the timing of magma movements in the subsurface shortly before the eruption is a key factor to unraveling the significance of phenomena affecting the Campi Flegrei during volcanic quiescence. Previous textural studies on the Monte Nuovo eruption (D'Oriano et al. 2005; Piochi et al. 2005) were hampered by the lack of crystallization kinetic data for trachytic-phonolitic melt compositions. To constrain the conditions and the timescales of magmatic processes, we focus on the crystallization kinetics of alkali feldspar in trachytic melts and new crystal size distribution (CSD) data for groundmass feldspars in the natural samples. This choice, although empirical (Brugger and Hammer 2010a; Eberl et al. 2002), is in line with several studies (e.g., Geschwind and Rutherford 1995; Hammer and Rutherford 2002; Couch et al. 2003; Armienti et al. 2007; Martel 2012) that used crystallization kinetics and CSD of feldspar (mainly plagioclase) to unravel shallow dynamics at several calc-alkaline volcanoes. Our new data (including potential complications regarding interpretations of natural textures, e.g., Brugger and Hammer 2010a; Eberl et al. 2002) provide a quantitative method (in the view of Brugger and Hammer 2010a) for studying magma dynamics using the abundant alkali feldspar crystals in the Campi Flegrei system.

\section{Volcanological background}

\section{The Monte Nuovo eruption}

The 1538 Monte Nuovo eruption (Fig. 1a-e) was characterized by relatively low intensity and magnitude (Di Vito et al. 1987; D'Oriano et al. 2005; Piochi et al. 2005, 2008). Similar to the majority of volcanic eruptions of the last $14.9 \mathrm{ka} \mathrm{BP}$ in the area (see Rosi et al. 1983; Di Vito et al. 1999; Isaia et al. 2009), it occurred from a monogenic vent and released $<0.1 \mathrm{~km}^{3}$ of magma (Lirer et al. 1987; Rosi and Sbrana 1987; Mormone et al. 2011) with a K-rich, phono-trachytic composition (Fig. 2). The erupted material consisted of variably vesicular pumice and scoria fragments with sparsely 
Fig. 1 The Monte Nuovo tuff cone location (a) with image of the lowermost ash to sand levels and the uppermost scoria deposits (b) and (c), respectively. The diagrams show the timing of the phenomena preceding the eruption since $1470 \mathrm{AD}(d)$ and 1538 (e), on the basis of Guidoboni and Ciuccarelli (2011). The panels (d) and (e) indicate the time of occurrence for seismicity (vertical bars), flow output (cloud), and ground deformation (arrows and dotted lines; right concavity inflation, left concavity deflation). The relation between phenomena and outcrops is also indicated. The onset for microlite growth as suggested by CSD is also indicated. The brown pumice and scoria samples' location is indicated by black boxes in panels (a) and (b). The sampling site of the early erupted yellow pumices of LM inf $d$ and LM inf 1 is indicated in panel (a)
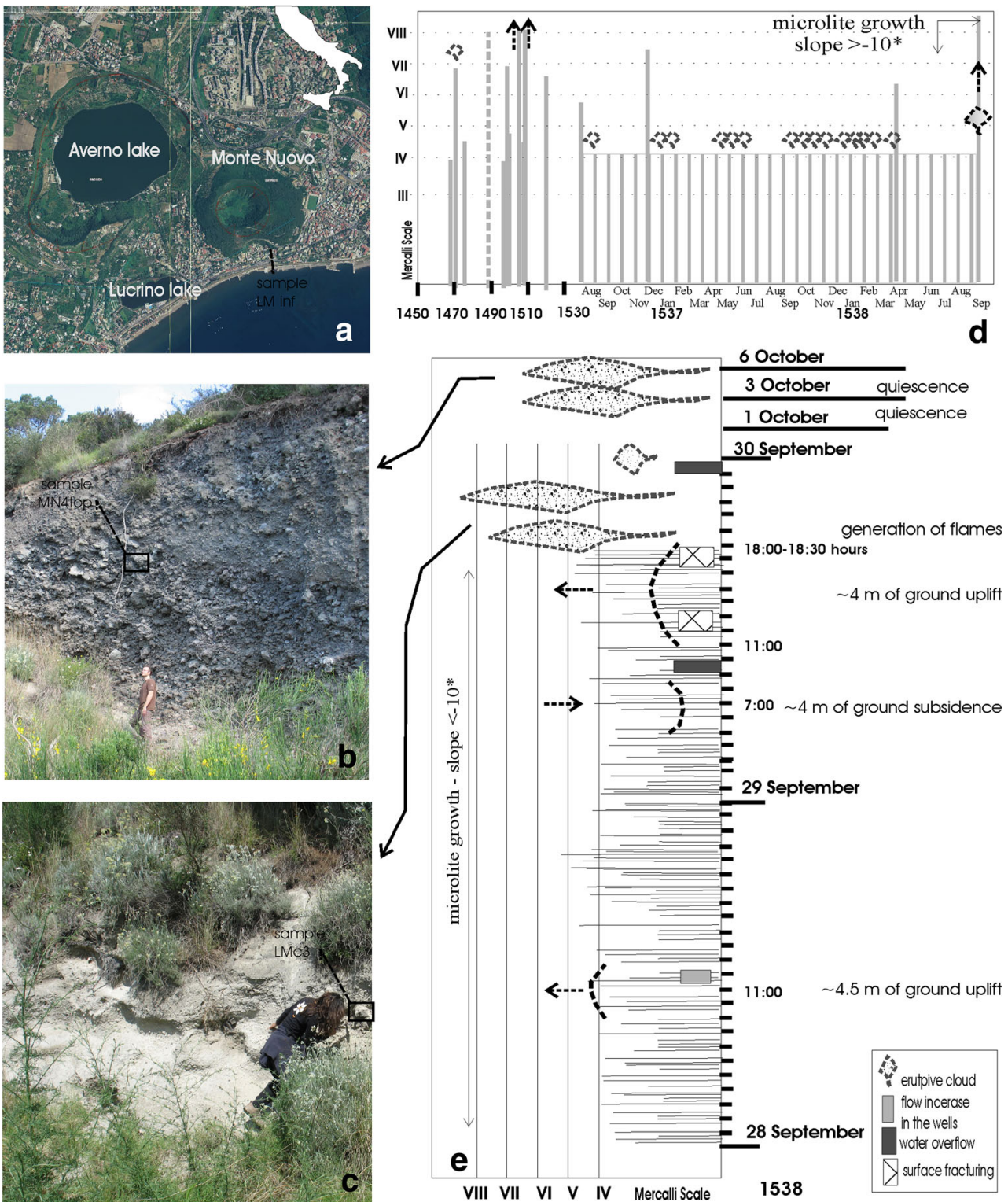

porphyritic texture and typically containing alkaline feldspars (e.g., Rosi and Sbrana 1987; Piochi et al. 2008; D'Oriano et al. 2005). However, the Monte Nuovo eruption seems to be an exceptional event in the Campi Flegrei history, given that in the past $14.9 \mathrm{ka}$, Campi Flegrei volcanism mostly concentrated in epochs of intense activity, alternating with quiescent periods of thousands of years; in such epochs eruptions occurred with a decadal frequency (Di Vito et al. 1999; Di Renzo
Fig. 2 TAS (Le Bas et al. 1986), on the left, and Alkali vs. $\mathrm{CaO}$, on the right, diagrams for the Monte Nuovo natural glasses and ZAC bulk rock (Table 1). Data on natural glass and whole rocks from Piochi et al. (2008), Rosi and Sbrana (1987), D’Oriano et al. (2005)

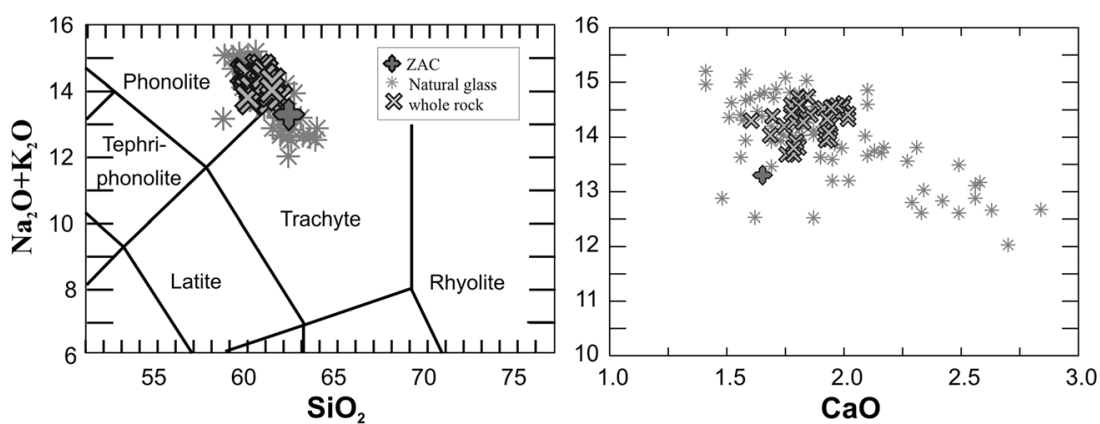


et al. 2011). Instead, the Monte Nuovo event was the last and occurred after a volcanic quiescence of $\sim 3000$ years.

The eruption started in the night between September 29th and 30th (Guidoboni and Ciuccarelli 2011), after an intensification of decadal fumarolic and bradyseism activity (Parascandola 1947; Lirer et al. 1987; Guidoboni and Ciuccarelli 2011) occurred about 3 months before the eruption (Guidoboni and Ciuccarelli 2011; Fig. 1d, e). The first phreato-magmatic phase produced pumiceous lapilli-bearing ash deposits (LM in D'Oriano et al. 2005; Units I-II in Di Vito et al. 1987) that built the cone. The main LM deposit is composed of coarse to fine ash and is coarser and lapilli bearing in the lowermost levels (Unit I), where it is intercalated with pumice or scoria lenses or beds (Boivin et al. 1982). This deposit was emplaced by pyroclastic flows. On October 3, after 2 days of diminishing intensity, explosions produced two dark scoriae layers intercalated with a gray ash bed (UM1 or Unit III, in D'Oriano et al. 2005 and Di Vito et al. 1987, respectively). The final phase, after 3 days of eruptive quiescence, produced a scoria unit deposited by pyroclastic flow (UM2 in D'Oriano et al. 2005) and/or fallout (Unit IV in Di Vito et al. 1987) mechanisms. D'Oriano et al. (2005) suggested that the UM1 scoria-bearing pyroclastic flows were originated by vulcanian-type explosions.

\section{Overview of previous studies}

The pumice and scoria fragments contain $<3 \%$ phenocrysts, consisting mostly of feldspars, with subordinate magnetite and rare spinel, and are microcrystalline, with a variety of textures (D'Oriano et al. 2005; Piochi et al. 2005, 2008). Pumices are mostly angular clasts, yellowish in color and with subspherical vesicles, from 2 to $30 \mathrm{~cm}$ in dimension (Di Vito et al. 1987). Other pumices are characterized by alternating yellow and brown portions and are referred to as banded pumices. Scoriae are mostly blackish clasts, generally decimetersized (20-60 cm diameter; Di Vito et al. 1987), containing heterogeneous vesicles and often a more vesicular core and less vesicular margin, with elongated vesicles in some pumice fragments. Microlites are primarily alkali feldspars (sanidine and lesser anorthoclase), and microlite abundance varies with vesicularity. Microlites in highly vesicular pumice are less abundant and smaller than those in scoria clasts. Banded pumice fragments are characterized by strong parallel layering and variations in groundmass texture: brown bands are more crystalline and less vesicular than yellowish bands, which are similar to the yellowish pumice (Piochi et al. 2008). The microlites of banded pumices have generally acicular shape with larger sizes compared with those in scoriae; some of them are curved, following the shape of an adjacent vesicle, suggesting that they grew concomitantly with vesicle formation (Piochi et al. 2005, 2008). In pumices, microlites are weakly to strongly aligned, and microlites and color bands share the same alignment. Overall, the products are denser and more crystalline upwards in the sequence; at the same time, the temperatures suggested by ternary solvus feldspar microlites moves to higher values $\left(900\right.$ to $1000{ }^{\circ} \mathrm{C}$ ), as observed by D’Oriano et al. (2005) and Piochi et al. (2005). Piochi et al. (2008) also measured low water content in the glassy groundmass of pumice and scoriae; therefore, degassing was considered the driving force for crystallization. Measured CSDs display concave upward trends attributed to two crystal populations (D’Oriano et al. 2005; Piochi et al. 2005; Mastrolorenzo and Pappalardo 2006).

\section{Methods: synthetic and natural products}

\section{Synthetic products: starting material and experimental strategy}

We complement the experiments of Arzilli and Carroll (2013) to obtain a wider data set of feldspar crystallization conditions involving growth under isobaric cooling, isothermal decompression, and decompression + cooling experiments. The starting material (Table 1) is the same obsidian used in previous work; it was sampled within the Breccia Museo Unit, a pyroclastic breccia associated with the Campanian Ignimbrite eruption dated at c.a. $39 \mathrm{ka}$ (Melluso et al. 1995; Fedele et al. 2008). The sample is known as ZAC in the literature (Di Matteo et al. 2004; Fabbrizio and Carroll 2008; Calzolaio et al. 2010; Arzilli and Carroll 2013). It contains $<10 \%$ crystals by volume. Phenocrysts are mostly alkali feldspar with minor plagioclase, clinopyroxene, biotite, and magnetite, in order of decreasing abundance; apatite and titanite are accessory phases. The composition is trachytic, near the trachyte-

Table 1 Chemical composition of ZAC (from Di Matteo et al. 2004) and average for natural samples from units selected for this study (see Piochi et al. 2008 for original, not $\mathrm{H}_{2} \mathrm{O}$-free normalized data)

\begin{tabular}{lrrrr}
\hline Oxide $(w t \%)$ & \multicolumn{1}{c}{ ZAC } & LM inf & \multicolumn{1}{c}{ LMc } & \multicolumn{1}{c}{ MN4 } \\
\hline $\mathrm{SiO}_{2}$ & 62.18 & 60.76 & 60.77 & 63.71 \\
$\mathrm{TiO}_{2}$ & 0.45 & 0.42 & 0.43 & 0.31 \\
$\mathrm{Al}_{2} \mathrm{O}_{3}$ & 18.70 & 19.09 & 19.39 & 19.91 \\
$\mathrm{FeO} *$ & 3.19 & 3.05 & 3.05 & 1.63 \\
$\mathrm{MnO}$ & 0.27 & 0.27 & 0.27 & 0.07 \\
$\mathrm{MgO}$ & 0.23 & 0.23 & 0.24 & 0.12 \\
$\mathrm{CaO}$ & 1.65 & 1.89 & 1.94 & 1.55 \\
$\mathrm{Na}$ & 6.16 & 7.09 & 6.82 & 6.67 \\
$\mathrm{~K}_{2} \mathrm{O}$ & 7.14 & 7.17 & 7.08 & 6.04 \\
$\mathrm{P}_{2} \mathrm{O}_{5}$ & 0.02 & 0.03 & 0.02 & 0.01 \\
$\mathrm{Total}$ & 100.00 & 100.00 & 100.00 & 100.00 \\
\hline
\end{tabular}

$\mathrm{FeO} *$ total iron as $\mathrm{FeO}$ 
phonolite border in the TAS diagram (Di Matteo et al. 2004). It is similar but not identical to the Monte Nuovo products in terms of whole-rock and glassy matrix chemistry (Fig. 2; Table 1). There are also small differences in phenocryst contents ( $<10 \%$ ZAC vs. $3 \%$ Monte Nuovo) and mineral assemblage (slight abundance of pyroxene and biotite in ZAC). Despite these small differences, we used ZAC because the phase diagram (Fabbrizio and Carroll 2008; Arzilli and Carroll 2013) allowed us to choose accurately the experimental conditions relevant for our study on the feldspar crystallization kinetic. In addition, Piochi et al. (2008) proposed a similar composition for the magma systems feeding many eruptions at the Campi Flegrei.

To complement the experimental data of Arzilli and Carroll (2013), we have performed 16 new crystallization experiments. Particularly, we extend cooling and degassing experiments in water-saturated conditions towards higher pressure (experimental final pressure, $P_{\mathrm{f}}=100,150$, and $200 \mathrm{MPa}$ ) and lower pressure $\left(P_{\mathrm{f}}=30\right.$ and $\left.50 \mathrm{MPa}\right)$ within a range of temperatures between 750 and $850{ }^{\circ} \mathrm{C}$ (Table 2). We performed isobaric cooling and isothermal decompression experiments with experimental durations not already investigated by Arzilli and Carroll (2013). In addition, decompression + cooling experiments present different initial temperatures and experimental durations (see Table 2) relative to those performed by Arzilli and Carroll (2013). The amount of $\mathrm{H}_{2} \mathrm{O}$ needed to achieve water saturation was estimated using the $\mathrm{H}_{2} \mathrm{O}$ solubility data of Di Matteo et al. (2004). The initial conditions of the experiments were above the liquidus of the alkali feldspar. The experiments were carried out using cold seal pressure vessels (CSPV) at the Geology Division (University of Camerino), using Nimonic 105 alloy cold-seal bombs. The bombs were pressurized using water as the pressure medium. The redox conditions of the apparatus are $\sim 0.8$ $\log f \mathrm{O}_{2}$ units above the NNO buffer (Di Matteo et al. 2004). The temperature was measured with a K-type (chromelalumel) thermocouple, with an accuracy of $\pm 5{ }^{\circ} \mathrm{C}$. Cold seal pressure vessels were equipped with rapid quench extensions, allowing samples to be dropped into a water-cooled chamber at the end of the experiments (Arzilli and Carroll 2013). The samples were cooled, reaching ambient temperature in a few seconds, with quench rates of $\sim 150^{\circ} \mathrm{C} / \mathrm{s}$ (Dobson et al. 1989; Carroll and Blank 1997). Capsules $\left(\mathrm{Ag}_{70}-\mathrm{Pd}_{30}\right)$ were filled with $\mathrm{ZAC}$ powder and $\mathrm{H}_{2} \mathrm{O}$ (slightly more than the amount of $\mathrm{H}_{2} \mathrm{O}$ needed to reach the saturation condition) and then sealed to obtain a closed system. Capsules were weighed after each experiment to check for changes in weight, and capsules with no weight change were deemed successful.

Table 2 Experimental conditions for isothermal cooling, decompression + cooling and isothermal decompression experiments

\begin{tabular}{|c|c|c|c|c|c|c|c|c|c|}
\hline Sample & $T_{i}\left({ }^{\circ} \mathrm{C}\right)$ & $T_{\mathrm{f}}\left({ }^{\circ} \mathrm{C}\right)$ & $P(\mathrm{MPa})$ & $t_{\mathrm{m}}(\mathrm{s})$ & $t_{\exp }(\mathrm{s})$ & ${ }^{*} \mathrm{H}_{2} \mathrm{O}(\mathrm{wt} \%)$ & $\Delta T\left({ }^{\circ} \mathrm{C}\right)$ & \multicolumn{2}{|l|}{$-\Delta T\left({ }^{\circ} \mathrm{C}\right)$} \\
\hline \multicolumn{10}{|c|}{ Isobaric cooling experiments } \\
\hline D20 & 900 & 750 & 200 & 72,000 & 28,800 & 7 & 20 & 131 & \\
\hline D15 & 900 & 775 & 150 & 7200 & 7200 & 6 & 17 & 108 & \\
\hline D13 & 880 & 775 & 150 & 7200 & 28,800 & 6 & 17 & 88 & \\
\hline D6 & 880 & 800 & 100 & 7200 & 21,600 & 5.2 & 19 & 61 & \\
\hline D11 & 900 & 850 & 50 & 7200 & 7200 & 2.7 & 15 & 35 & \\
\hline D12 & 900 & 850 & 50 & 7200 & 14,400 & 2.7 & 15 & 35 & \\
\hline D33 & 900 & 840 & 50 & 7200 & 14,400 & 2.7 & 25 & 35 & \\
\hline D10 & 900 & 825 & 50 & 7200 & 28,800 & 2.7 & 40 & 35 & \\
\hline D9 & 900 & 825 & 50 & 7200 & 57,600 & 2.7 & 40 & 35 & \\
\hline D69 & 880 & 750 & 50 & 7200 & 21,600 & 2.7 & 115 & 15 & \\
\hline D78 & 880 & 750 & 50 & 7200 & 50,400 & 2.7 & 115 & 15 & \\
\hline Sample & $T_{i}\left({ }^{\circ} \mathrm{C}\right)$ & $T_{\mathrm{f}}\left({ }^{\circ} \mathrm{C}\right)$ & $P_{i}(\mathrm{MPa})$ & $P_{\mathrm{f}}(\mathrm{MPa})$ & $t_{\mathrm{m}}(\mathrm{s})$ & $t_{\exp }(\mathrm{s})$ & ${ }^{*} \mathrm{H}_{2} \mathrm{O}(\mathrm{wt} \%)$ & $\Delta T\left({ }^{\circ} \mathrm{C}\right)$ & $-\Delta T\left({ }^{\circ} \mathrm{C}\right)$ \\
\hline \multicolumn{10}{|c|}{ Decompression + cooling experiments } \\
\hline D17 & 825 & 775 & 200 & 150 & 72,000 & 21,600 & 6 & 17 & 56 \\
\hline D25 & 825 & 775 & 200 & 150 & 72,000 & 57,600 & 6 & 17 & 56 \\
\hline D29 & 825 & 800 & 200 & 100 & 7200 & 57,600 & 5.2 & 19 & 56 \\
\hline D21 & 825 & 825 & 200 & 50 & 7200 & 57,600 & 2.7 & 40 & 56 \\
\hline \multicolumn{10}{|c|}{ Isothermal decompression experiments } \\
\hline D62 & 825 & 825 & 150 & 30 & 3600 & 50,400 & 1.7 & 65 & 33 \\
\hline
\end{tabular}

$* \mathrm{H}_{2} \mathrm{O}(\mathrm{wt} \%)$ was calculated using the polynomial fit by Di Matteo et al. (2004)

$T_{i}$ initial (or melting) temperature, $T_{\mathrm{f}}$ final (or experimental) temperature, $P_{i}$ initial (or melting) pressure, $P_{\mathrm{f}}$ final (or experimental) pressure, $t_{\mathrm{m}}$ melting time, $t_{\exp }$ experimental time, $\Delta T$ the undercooling degree, $-\Delta T$ the superheating degree 


\section{Natural products}

Analyzed pumice and scoria fragments are from the Lower and Upper Members of the Monte Nuovo formation (Fig. 1a-c), respectively. Fragments and eruption levels were selected on the basis of previous textural and chemical characterization (D’Oriano et al. 2005; Piochi et al. 2005; Piochi et al. 2008) with the aim of analyzing in greater detail (including new X-ray diffraction data) the textural and petrological variability in the eruption products. In particular, we focus on pumices from the base of the sequence (samples LM inf $d$ and LM inf 1; Fig. 1a) and top scoriae (MN4top; Fig. 1b and Fig. 3b). The basal pumices are interpreted to have formed by fragmentation involving some interaction with external water during magma ascent. Textural evidence for this (Fig. 3) includes (i) vesicle walls that are broken and display shock-induced cracks, (ii) higher vesicularities (up to $80 \%$ ) than other pumices and scoriae, and (iii) lower groundmass crystallinity. These pumices have higher $\mathrm{H}_{2} \mathrm{O}$ contents $(1.11 \pm 0.16 \mathrm{wt} \%$; Piochi et al. 2008) than products higher in the sequence. In contrast, the MN4top scoriae are interpreted to have formed by degassing of magmatic volatiles during rapid ascent and resultant magma fragmentation (D’Oriano et al. 2005; Piochi et al. 2008). The MN4top scoriae have low $\mathrm{H}_{2} \mathrm{O}$ contents $(0.21 \pm 0.05 \mathrm{wt} \%$; Piochi et al. 2008). We also consider brown and yellow sectors in banded pumices from LM (LMC3; Fig. 1c) in order to examine the entire textural range.

\section{Analytical methods}

\section{SEM and image analyses}

Electron microscope images were taken for both synthetic and natural samples in order to obtain detailed information on textural features and mineralogical assemblage (Figs. 3, 4, and 5). Backscattered electron (BSE) images were collected for
Fig. 3 Groundmass texture of natural pumice (samples c1 1-7, c2s 9-12, infl 8-12, infsc 02-05) and scoriae (samples MN3/1, MN4top) from base upwards in the stratigraphic sequence. Samples MN3/1 (a) and MN4top (b) are two scoriae in the upper part of the sequence. Note the cuspate shape of vesicle and the magnetite occurrence in the most crystalline and poorly vesiculated MN4top. Samples c1 1-7 (c) and c2s 9-12 (d) show the groundmass crystallinity and vesicularity feature of a yellowish and a brown pumice, respectively, within the main pyroclastic unit. Note the microlite alignment and the curved shape of several crystals. Rare microlites and high vesiculation characterize pumice at the base of the flow sequence. In particular, sample infl 8-12 (e) shows the cracks (white arrows) produced by water/magma interaction. Sample infsc 02-05 (f) is a banded pumice within the main pyroclastic unit characterized by low crystal abundance and higher vesiculation of yellowish band (on the left) with respect of the adjacent brown sector. White bars are $100 \mu \mathrm{m}$
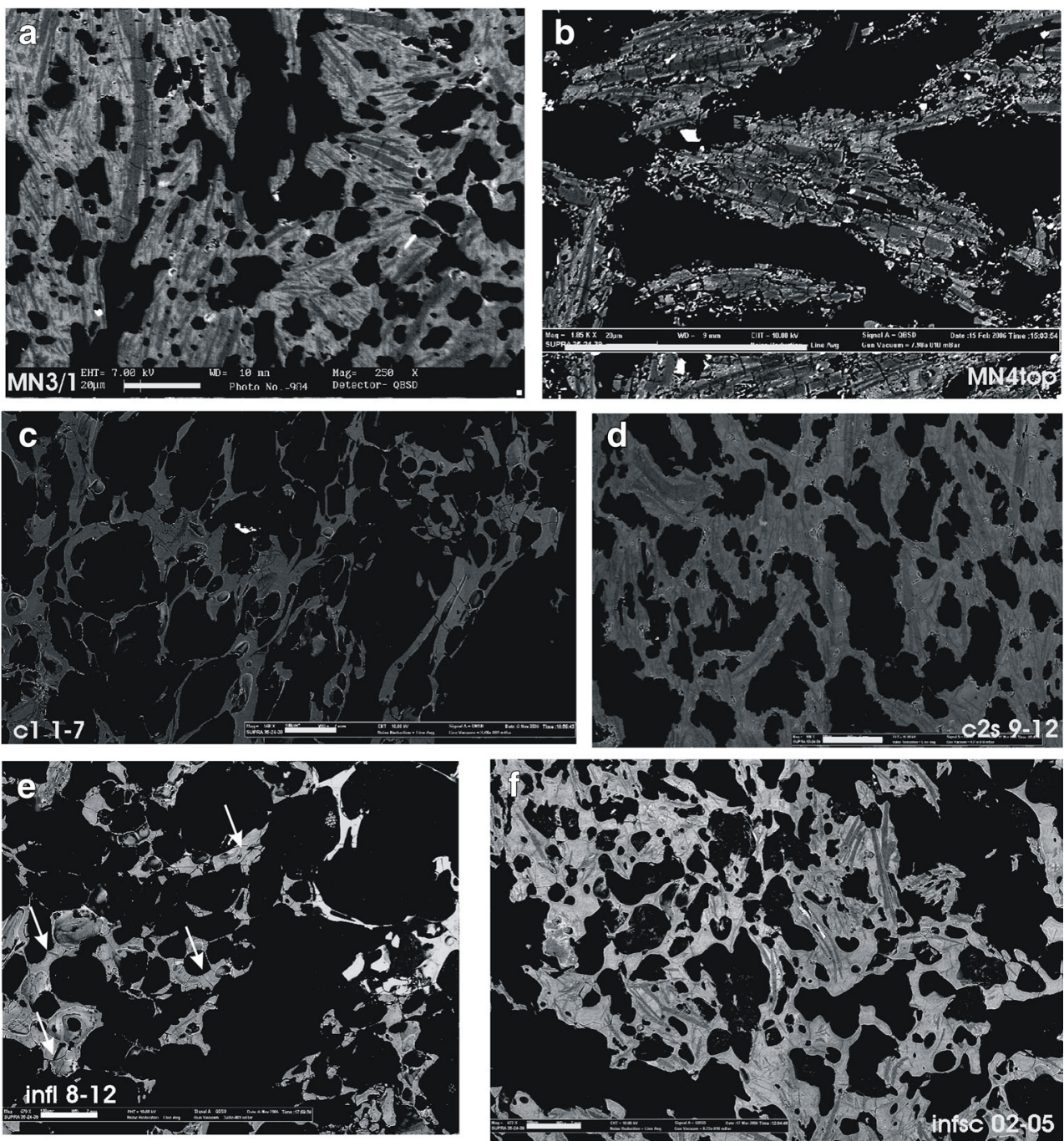

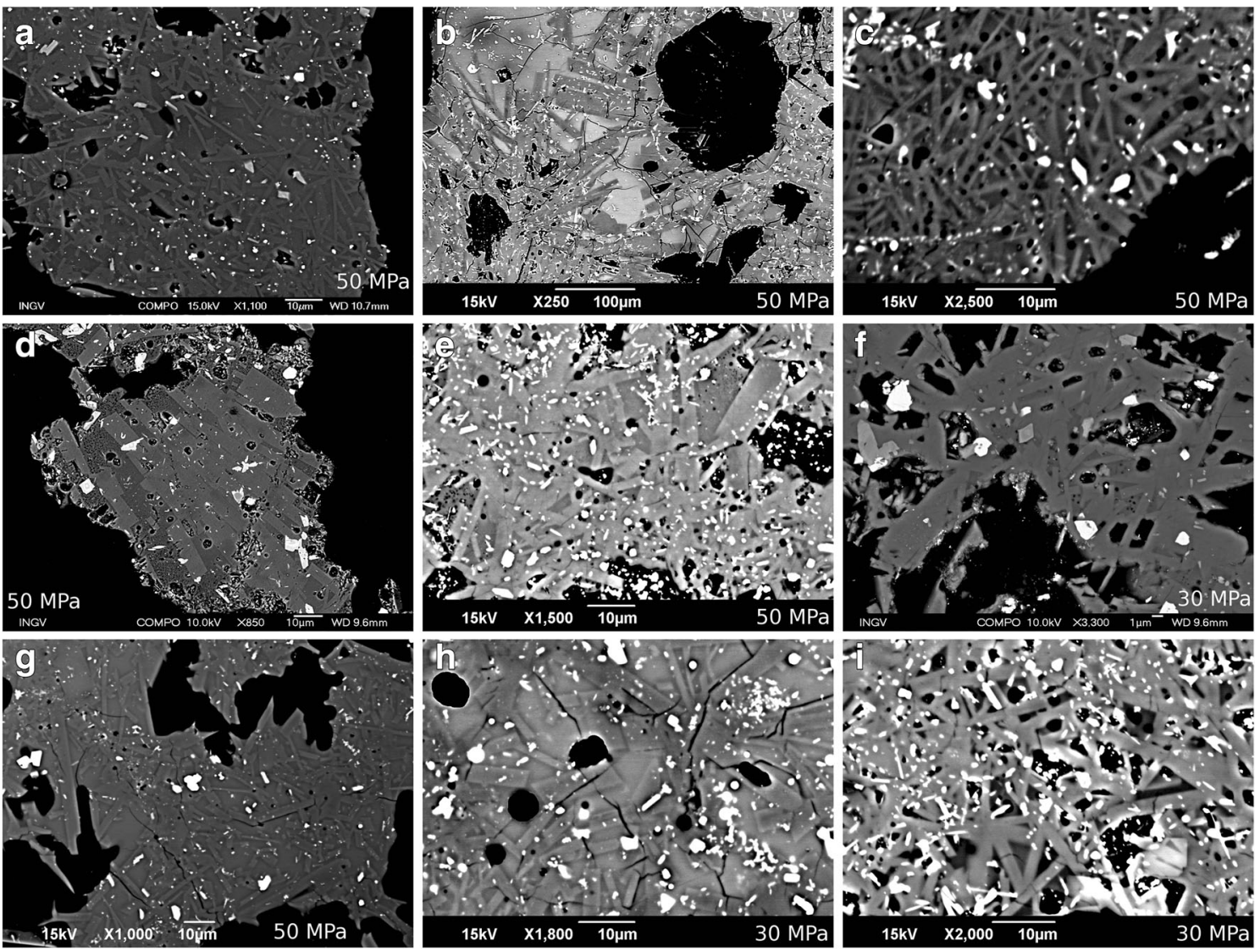

Fig. 4 Backscattered SEM images of textures obtained at low pressure (50 and $30 \mathrm{MPa}$ ) from isobaric cooling, decompression + cooling and isothermal decompression experiments. Cooling experiments: a D33 $\left(P_{\mathrm{f}}=50 \mathrm{MPa}, \Delta T=25^{\circ} \mathrm{C}\right) ; \mathbf{b} \mathrm{D} 10\left(P_{\mathrm{f}}=50 \mathrm{MPa}, \Delta T=40^{\circ} \mathrm{C}\right) ; \mathbf{c} \mathrm{D} 69$ $\left(P_{\mathrm{f}}=50 \mathrm{MPa}, \Delta T=115^{\circ} \mathrm{C}\right)$. Decompression + cooling experiments: $\mathbf{d}$ D45 $\left(P_{\mathrm{f}}=50 \mathrm{MPa}, \Delta T=115^{\circ} \mathrm{C}\right)$; e D43 $\left(P_{\mathrm{f}}=50 \mathrm{MPa}, \Delta T=115^{\circ} \mathrm{C}\right) ; \mathbf{f}$

D47 $\left(P_{\mathrm{f}}=30 \mathrm{MPa}, \Delta T=140{ }^{\circ} \mathrm{C}\right)$. Isothermal decompression experiments: g D57 $\left(P_{\mathrm{f}}=50 \mathrm{MPa}, \Delta T=40{ }^{\circ} \mathrm{C}\right)$; h D60 $\left(P_{\mathrm{f}}=30 \mathrm{MPa}\right.$, $\left.\Delta T=65^{\circ} \mathrm{C}\right)$; i D62 $\left(P_{\mathrm{f}}=30 \mathrm{MPa}, \Delta T=65^{\circ} \mathrm{C}\right)$. The samples D33, D10, D69, and D62 were performed in this study; the other ones are data of Arzilli and Carroll (2013)

experimental samples using a JEOL JSM-6390LA FE-SEM at the Institute of Geochemistry and Petrology, ETH Zurich, and JEOL JSM-6500F-upgraded to 7000 series-FEG at the INGV of Rome. BSE images of pumices and scoriae of Monte Nuovo were acquired using a LEO 430 SEM at "Istituto Geomare Sud-CNR" of Naples, Italy and a ZEISS SUPRA 35 at the "Dipartimento di Ingegneria dell'Informazione" of the II Università di Napoli in Aversa, Italy, operating at $10 \mathrm{kV}$, and a working distance of 15 and 7-12 $\mathrm{mm}$, respectively.

Textural analysis on BSE images was performed using ImageJ software (NIH Image; Abramoff et al. 2004; Schneider et al. 2012) to obtain crystallization kinetics data for alkali feldspar. Nucleation and growth kinetics were calculated using the batch method (Hammer and Rutherford 2002; Couch et al. 2003; Brugger and Hammer 2010a, b). Imaging analyses were performed to measure the number of alkali feldspar crystals and the area of each phase (crystal phases, glass, and bubbles) in every (both synthetic and natural) sample. The number of alkali feldspar crystals $\left(n_{\text {Fsp }}\right)$ was measured to calculate the crystal number density $\left(N_{\mathrm{a}}\right.$, crystals/

$\left.\mathrm{cm}^{2}\right) . N_{\mathrm{a}}$ and crystal area fraction $(\phi)$ of alkali feldspar were calculated on a vesicle-free basis. The relevant area $\left(A_{\mathrm{r}}\right)$ in each BSE image consists of only glass and crystal phases, thus, all abundances refer to phase proportions in glass plus crystals (vesicle-free basis; e.g., Hammer et al. 1999). $N_{\mathrm{a}}$ of alkali feldspar was obtained through the relation (Hammer et al. 1999):

$N_{\mathrm{a}}=\frac{n_{\text {Fsp }}}{A_{\mathrm{r}}}$

The alkali feldspar volume fraction $(\phi)$ was obtained from (Hammer et al. 1999):

$\phi=\frac{A_{\mathrm{Fsp}}}{A_{\mathrm{r}}}$

where $A_{\mathrm{Fsp}}$ is the area of the alkali feldspar. Since alkali feldspar crystals and trachytic glass have similar average atomic number, BSE images often showed low contrast between these two phases. Therefore, the separation of alkali feldspar 

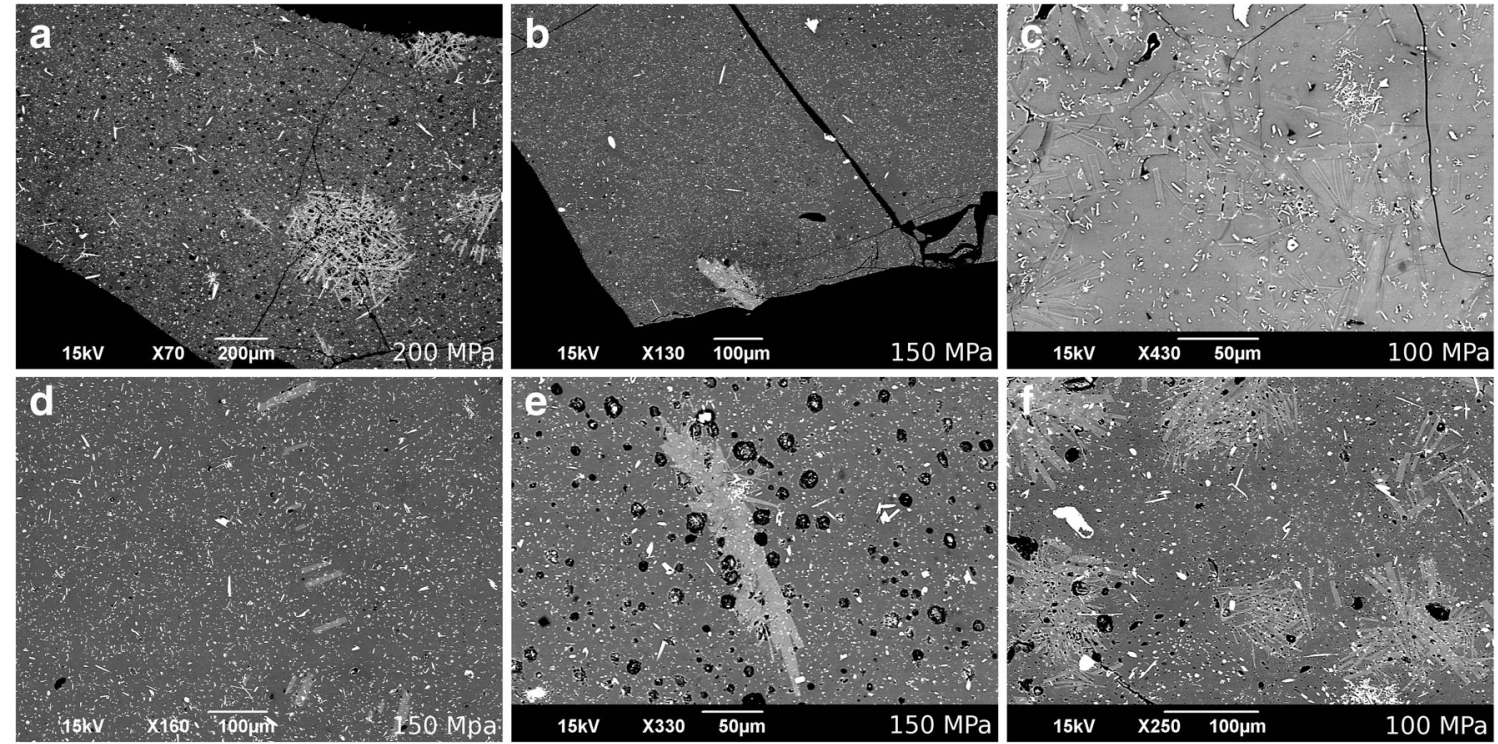
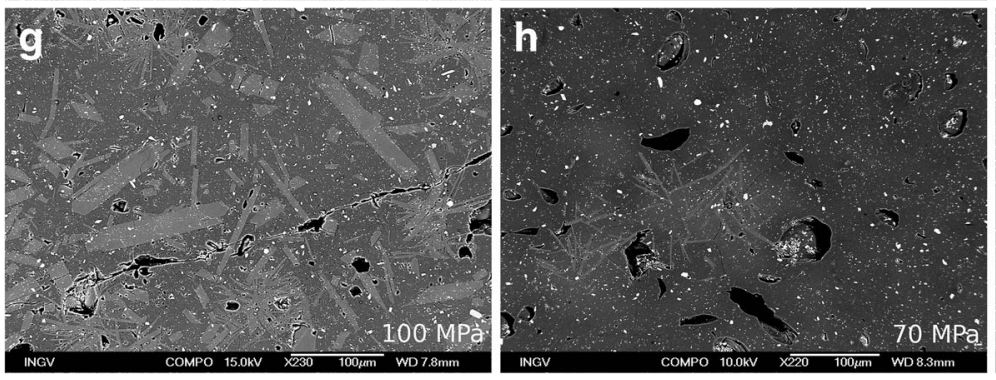

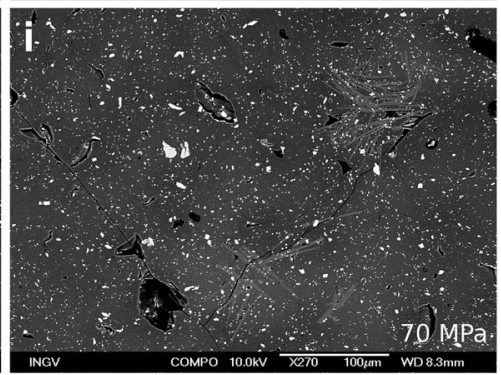

Fig. 5 Backscattered SEM images of textures obtained at high pressure $(200,150,100$, and $70 \mathrm{MPa})$ from isobaric cooling, decompression + cooling, and isothermal decompression experiments. Cooling experiments: a $\mathrm{D} 1\left(P_{\mathrm{f}}=200 \mathrm{MPa}, \Delta T=20{ }^{\circ} \mathrm{C}\right)$; b D 15 $\left(P_{\mathrm{f}}=150 \mathrm{MPa}, \Delta T=17{ }^{\circ} \mathrm{C}\right)$; c D6 $\left(P_{\mathrm{f}}=100 \mathrm{MPa}, \Delta T=19^{\circ} \mathrm{C}\right)$. Decompression + cooling experiments: d D17 $\left(P_{\mathrm{f}}=150 \mathrm{MPa}\right.$,

from glass was difficult using only thresholding segmentation and many crystals had to be defined manually. The areas of clinopyroxenes, oxides, and bubbles were measured using simple thresholding because their gray tones were clearly distinguishable. The uncertainty in the area measurements was estimated on the basis of 10 images per sample. An area from 0.022 to $0.58 \mathrm{~mm}^{2}$ was used for image analyses of natural samples.

For the synthetic samples, the following parameters were also calculated. Mean crystal size $\left(s_{n}\right)$ was also calculated through the following equation:

$S_{n}=\sqrt{\frac{\phi}{N_{\mathrm{a}}}}$

The volumetric number density $\left(N_{\mathrm{v}}\right)$ calculation uses a standard method for correcting the area to volumetric nucleation density (Cheng and Lemlich 1983; Couch 2003):

$N_{\mathrm{v}}=\frac{N_{\mathrm{a}}}{S_{n}}$
$\left.\Delta T=17{ }^{\circ} \mathrm{C}\right)$; e $\mathrm{D} 55\left(P_{\mathrm{f}}=150 \mathrm{MPa}, \Delta T=42{ }^{\circ} \mathrm{C}\right)$; f D51 $\left(P_{\mathrm{f}}=100 \mathrm{MPa}, \Delta T=69^{\circ} \mathrm{C}\right)$. Isothermal decompression experiments: $\mathbf{g}$ $\mathrm{D} 80\left(P_{\mathrm{f}}=100 \mathrm{MPa}, \Delta T=19^{\circ} \mathrm{C}\right) ; \mathbf{h} \mathrm{D} 82\left(P_{\mathrm{f}}=70 \mathrm{MPa}, \Delta T=14^{\circ} \mathrm{C}\right) ; \mathbf{i}$ D82 $\left(P_{\mathrm{f}}=70 \mathrm{MPa}, \Delta T=14{ }^{\circ} \mathrm{C}\right)$. The samples D15, D6, and D17 were performed in this study; the other ones are data of Arzilli and Carroll (2013)

The batch nucleation rate, $I_{\mathrm{m}}$ (Hammer and Rutherford 2002; Couch 2003; Brugger and Hammer 2010a; Shea and Hammer 2013) was calculated from the following:

$I_{\mathrm{m}}=\frac{N_{\mathrm{v}}}{t}$

where $t$ is the experimental duration. Alkali feldspar crystal dimensions were also measured on BSE images using ImageJ software. Typically, only the largest 10 crystals in each image were measured (e.g., Couch 2003) to determine the maximum growth rate. Growth rate $\left(Y_{\mathrm{L}}\right)$ was calculated using only the longest dimension of each crystal (e.g., Fenn 1977; Swanson 1977; Hammer and Rutherford 2002; Couch et al. 2003). The uncertainty for sizes and growth rate measurements was estimated on the basis of the 10 largest crystals observed in each sample. The maximum growth rate of alkali feldspar was calculated through the following relation (Swanson 1977; Couch et al. 2003; Shea and Hammer 2013):

$Y_{\mathrm{L}}=\frac{0.5 L}{t}$ 
where $t$ is the duration of the experiment. The mean growth rate $\left(Y_{S_{n}}\right)$ was calculated from the equation (Brugger and Hammer 2010a, b):

$Y_{s_{n}}=\frac{S_{n}}{t}$

The difference between $Y_{\mathrm{L}}$ and $Y_{S_{n}}$ is that $Y_{\mathrm{L}}$ is the maximum growth rate obtained during the experiment, whereas $Y_{S_{n}}$ is the mean growth rate calculated using the mean crystal size $\left(S_{n}\right)$.

\section{Crystal size distribution analysis}

Fragments from selected natural samples were used for CSD measurements to estimate the magma residence time based on the relationship between feldspar population density, crystal sizes, and experimentally determined growth rates of alkali feldspar. CSD studies provide quantitative information on relations between crystal population density and crystal length for a population of crystals. The linear relation provides estimates of timescales of magmatic processes (Marsh 1988; Cashman and Marsh 1988). The slope of the correlation is equal to $-1 /$ (growth rate $\times$ residence time), and the intercept is equal to the nucleation density (Higgins 2000).

Crystal dimensions and abundances of each size population were recovered through image analyses of BSE images and Adobe Photoshop ${ }^{\circledR}$ software. The crystals were manually segmented because of the weak contrast between trachytic glass and feldspar microlites. We were able to define the contour of each single crystal also in agglomerate structures. However, for highly crystalline samples, defining the geometry of each crystal involved some interpretation. Several assumptions were made to define different crystal geometries in agglomerates but they provided similar results. The reconstructed image was processed through ImageJ software (NIH Image; Abramoff et al. 2004; Schneider et al. 2012) to quantify data on crystallinity percentage and crystal sizes. The relationship between crystal population density and crystal length for a population of crystals was then obtained using the CSD Corrections 1.3 program (Higgins 2000, 2002).

\section{X-ray diffraction analysis}

Selected whole-rock samples and related hand-picked shards from the same sampled units used for CSD were examined by $\mathrm{X}$-ray powder diffraction (XRD). Samples were powdered in an agate mortar and analyzed $(\sim 1 \mathrm{~g}$ per sample) by XRD to further characterize mineralogy and to make semi-quantitative estimates of phase proportions on a larger amount of sample than that studied in thin sections.

The XRD patterns were obtained by using a Panalytical X'Pert Pro diffractometer of the Istituto Nazionale di
Geofisica e Vulcanologia, sezione Osservatorio Vesuviano (Naples, Italy), as described in Mormone et al. (2014). Operating conditions were $\mathrm{CuK} \alpha$ radiation, $40 \mathrm{kV}, 40 \mathrm{~mA}$, $2 \theta$ range from $3^{\circ}$ to $100^{\circ}$, equivalent step size $0.0179^{\circ} 2 \theta$, equivalent counting time $298.09 \mathrm{~s}$ per step. The X'Pert High Score Plus $2.2 \mathrm{~d}$ software allows qualitative and semiquantitative data of the analyzed natural powders. Semiquantitative XRD analysis was carried out on 7 samples using the X'Pert High Score Plus 3.0e package interface. The X-ray diffraction analysis, without internal standard, can provide semi-quantitative phase proportions which are reported on an amorphous-material-free basis. Detection limit for phase abundance is $\sim 0.3 \mathrm{wt} \%$.

\section{Results}

\section{Experimental samples: crystallization kinetics and textural features}

The experimental run products contain one or more of the following phases: alkali feldspar, clinopyroxene, Fe-Ti oxide, biotite, sodalite, glass and vesicles (Table 3). Sodalite (Table 3) is formed only at pressures $\leq 50 \mathrm{MPa}$, and it occurs in experiments with high crystal fractions of alkali feldspar $(\phi)$. The abundances of clinopyroxene, biotite, and magnetite remain low (0.01 to 0.10$)$ for the trachytic bulk composition.

Few quench feldspar crystals are present in our samples. Some tiny, acicular, and curved-shape feldspar crystals are visible in the run products (Fig. 5). They were not included in the data that were used to estimate the kinetics of crystallization. Because we used cold seal pressure vessels fitted with rapid quench extensions, the quench was very rapid and quench crystal formation was minimal.

The experiments were texturally analyzed to quantify the number densities $\left(N_{\mathrm{a}}\right)$, nucleation rates $\left(I_{\mathrm{m}}\right)$, crystallinities $(\phi)$, crystal lengths $(L)$ and growth rates $\left(Y_{\mathrm{L}}\right)$ of alkali feldspar (Table 3). The experiments between 50 and 200 MPa pressure show that the number density of alkali feldspar ranges from $10^{4}$ and $10^{6} \mathrm{~cm}^{-2}$ (Table 3) and the order of magnitude of $N_{\mathrm{a}}$ increases with decreasing pressure. The run products have a wide range of crystallinities of alkali feldspar $(\phi)$ that varies between 0.01 and 0.95 . The cooling experiments produced $\phi$ ranges from 0.01 to 0.93 , whereas decompression + cooling experiments exhibit $\phi$ variations from 0.05 to 0.72 . The feldspar fraction $\phi$ reaches a maximum of 0.95 at $30 \mathrm{MPa}$ and long duration $(14 \mathrm{~h})$ during an isothermal decompression experiment.

The experiments at high pressure $(100,150$, and $200 \mathrm{MPa})$ and short experimental duration (7200-28,800 s) show that $\phi$ changes from 0.01 to 0.32 with increasing duration (Table 3), whereas for the same pressures but at longer duration $(57,600 \mathrm{~s}) \phi$ is $\sim 0.42$. For the experiments at $50 \mathrm{MPa}$ and 
Table 3 Experimental results of nucleation and growth of alkali feldspar during isothermal cooling, decompression + cooling, and isothermal decompression experiments

\begin{tabular}{|c|c|c|c|c|c|c|c|}
\hline Sample & $N_{\mathrm{a}}\left(\mathrm{cm}^{-2}\right)$ & $\phi$ & $I_{\mathrm{m}}\left(\mathrm{cm}^{-3} \mathrm{~s}^{-1}\right)$ & $L(\mathrm{~cm})$ & $Y_{\mathrm{L}}(\mathrm{cm} / \mathrm{s})$ & $Y_{S_{n}}(\mathrm{~cm} / \mathrm{s})$ & Phases \\
\hline \multicolumn{8}{|c|}{ Isobaric cooling experiments } \\
\hline $\mathrm{D} 20$ & $4.6 \mathrm{E}+04(1)$ & $0.32(0.02)$ & $6.2 \mathrm{E}+02(3)$ & $0.0260(0.0095)$ & $4.5 \mathrm{E}-07(9)$ & $9.0 \mathrm{E}-08(3)$ & gl-af-cpx-mt-bt-bl \\
\hline D15 & nd & 0.01 & nd & nd & nd & nd & gl-af-cpx-mt-bt-bl \\
\hline D13 & $1.31 \mathrm{E}+04(1)$ & $0.04(0.01)$ & $2.6 \mathrm{E}+02(3)$ & $0.0116(0.0020)$ & $2.0 \mathrm{E}-07(4)$ & $6.1 \mathrm{E}-08(8)$ & gl-af-cpx-mt-bt-bl \\
\hline D6 & $4.62 E+04(1)$ & $0.17(0.01)$ & $1.11 \mathrm{E}+03(3)$ & $0.0182(0.0032)$ & $2.8 \mathrm{E}-07(4)$ & $8.9 \mathrm{E}-08(3)$ & gl-af-cpx-mt-bl \\
\hline D11 & $2.90 \mathrm{E}+05(4)$ & $0.29(0.01)$ & $4.0 \mathrm{E}+04(1)$ & $0.0107(0.0035)$ & 7.4E-07(2) & $1.38 \mathrm{E}-07(3)$ & gl-af-cpx-mt-bl \\
\hline D12 & $1.26 \mathrm{E}+06(1)$ & $0.32(0.01)$ & $1.74 \mathrm{E}+05(3)$ & $0.0096(0.0019)$ & $3.3 \mathrm{E}-07(7)$ & $3.49 \mathrm{E}-08(4)$ & gl-af-cpx-mt-bl \\
\hline D33 & $7.1 \mathrm{E}+06(1)$ & $0.49(0.01)$ & $1.85 \mathrm{E}+06(4)$ & $0.0041(0.0006)$ & $1.4 \mathrm{E}-07(2)$ & $1.84 \mathrm{E}-08(3)$ & af-cpx-mt-gl-bl \\
\hline D10 & $6.97 \mathrm{E}+05(2)$ & $0.52(0.02)$ & $8.9 \mathrm{E}+02(4)$ & $0.0116(0.0020)$ & $2.0 \mathrm{E}-07(3)$ & $9.4 \mathrm{E}-08(2)$ & af-cpx-mt-gl-bl \\
\hline D9 & $1.41 E+06(2)$ & $0.55(0.01)$ & $3.92 \mathrm{E}+04(8)$ & $0.0045(0.0011)$ & $3.9 \mathrm{E}-08(9)$ & $1.09 \mathrm{E}-08(2)$ & af-cpx-mt-gl-bl \\
\hline D69 & nd & $0.93(0.02)$ & nd & nd & nd & nd & af-cpx-mt-gl-bl-sod \\
\hline D78 & nd & $0.93(0.02)$ & nd & nd & nd & nd & af-cpx-mt-gl-bl-sod \\
\hline \multicolumn{8}{|c|}{ Decompression + cooling experiments } \\
\hline D17 & $1.23 \mathrm{E}+04(1)$ & $0.05(0.01)$ & $2.8 \mathrm{E}+02(3)$ & $0.0092(0.0022)$ & $2.13 \mathrm{E}-07(8)$ & $9.3 \mathrm{E}-08(9)$ & gl-af-cpx-mt-bt-bl \\
\hline D25 & $7.11 E+04(6)$ & $0.41(0.04)$ & $5.1 \mathrm{E}+02(3)$ & $0.0174(0.0032)$ & $1.51 \mathrm{E}-07(3)$ & $4.2 \mathrm{E}-08(2)$ & gl-af-cpx-mt-bt-bl \\
\hline D29 & $4.92 E+04(5)$ & $0.42(0.01)$ & $2.92 \mathrm{E}+02(5)$ & $0.0185(0.003)$ & $1.6 \mathrm{E}-07(3)$ & $5.07 \mathrm{E}-08(7)$ & gl-af-cpx-mt-bl \\
\hline D21 & $9.82 \mathrm{E}+06(3)$ & $0.72(0.03)$ & $6.3 \mathrm{E}+05(1)$ & $0.004(0.0012)$ & $3.5 \mathrm{E}+08(2)$ & $4.7 \mathrm{E}-09(1)$ & af-cpx-mt-gl-bl \\
\hline \multicolumn{8}{|c|}{ Isothermal decompression experiments } \\
\hline D62 & nd & $0.95(0.01)$ & nd & nd & nd & nd & af-cpx-mt-gl-bl-sod \\
\hline
\end{tabular}

Glass and crystalline phases are listed in approximate order of decreasing relative abundances

$N_{\mathrm{a}}$ nucleation density, $\phi$ volume fraction, $I_{\mathrm{m}}$ nucleation rate, $L$ maximum length, $Y_{\mathrm{L}}$ maximum growth rate, $Y_{S_{n}}$ mean growth rate. The value in parentheses is the standard deviation of the mean value. $n d$ not determined phases presents because the contrast between several phases is not sufficient to distinguish them in BSE images. $g l$ glass, $a f$ alkali feldspar, $c p x$ clinopyroxene, $m t$ magnetite, $b t$ biotite, $b l$ bubbles

$15 \leq \Delta T \leq 40{ }^{\circ} \mathrm{C}, \phi$ ranges between 0.29 and 0.55 (Table 3). Several samples (see D69, D78, D21, and D62 in Table 3) show that low pressure (30-50 MPa), $\mathrm{H}_{2} \mathrm{O}$ content (1.7$2.7 \mathrm{wt} \% \mathrm{H}_{2} \mathrm{O}$ ), and $40 \leq \Delta T \leq 115{ }^{\circ} \mathrm{C}$ result in extensive crystallization of alkali feldspar $(0.72 \leq \phi \leq 0.95)$. These samples have strongly intergrown textures characterized by a large quantity of tiny crystals (tabular and acicular crystal intergrowth) with very low abundance of glass (Fig. 4a-i). Alkali feldspars commonly have tabular and elongated rectangular shapes (Figs. $4 \mathrm{a}-\mathrm{i}$ and $5 \mathrm{~b}-\mathrm{d}$ ) at the different experimental conditions. In contrast, spherulitic alkali feldspar crystals are more common at higher $P_{\mathrm{f}}\left(=P_{\mathrm{H}_{2} \mathrm{O}}\right)$, and they are present in both cooling and decompression experiments (Fig. 5). Although it was difficult to obtain reliable chemical analysis, it was possible to establish that (1) alkali feldspars have less than $8 \mathrm{~mol} \%$ of An and 39 to $71 \mathrm{~mol} \%$ of Or and (2) residual glasses are trachytic in composition.

The maximum growth rates $\left(Y_{\mathrm{L}}\right)$ of alkali feldspar range between $10^{-8}$ and $10^{-7} \mathrm{~cm} / \mathrm{s}$ (Table 3). Values at the lower end of this range occur in experiments with longer duration $(57,600 \mathrm{~s})$, probably because of the closer approach to equilibrium at longer times. Table 3 also reports mean growth rates $\left(Y_{S_{n}}\right)$ determined using the batch method as described above
(Brugger and Hammer 2010a). As reported in Table 3, values of $Y_{\mathrm{L}}$ and $Y_{S_{n}}$ have similar orders of magnitude, but, as expected, maximum $Y_{\mathrm{L}}$ are higher than the mean $Y_{S_{n}}$ (Fig. 6). The batch nucleation rates $\left(I_{\mathrm{m}}\right)$ of alkali feldspar range between $10^{2}$ and $10^{6} \mathrm{~cm}^{-3} \mathrm{~s}^{-1}$, showing an increase at low $P_{\mathrm{f}}$ and high $\Delta T$ (Table 3 ).

\section{Natural samples: textural, XRD, and CSD data}

In natural samples, the dominant alkali-feldspar mineral phase is present in various percentages, from low abundance (nearly glassy matrix; Fig. 3e) to very high abundance (Fig. 3b). XRD data were used to evaluate the relative proportions of anorthoclase and sanidine and the accessory minerals present in the various samples (Table 4). The anorthoclase abundance is higher in the highly crystalline brown pumices (71-83\%) and scoriae $(55-60 \%)$. These samples also show small amounts of sodalite ( $\sim 3$ and $\sim 6 \%$, respectively). XRD data show trace amounts of biotite $(\leq 0.6 \%)$ in several pumice samples (Table 4), whereas it is absent in the scoriae erupted at the end of the eruption; these results are also consistent with petrographic observations. Particularly, the basal yellowish and the brown pumices have $\sim 0.5$ wt. $\%$ of biotite. A 


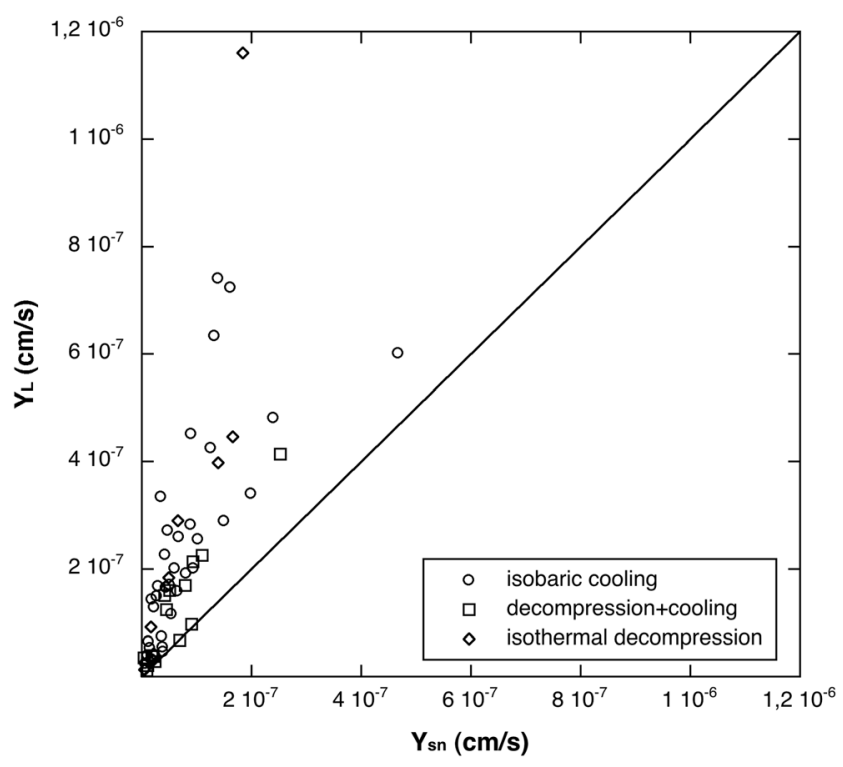

Fig. 6 Comparison between growth rate values $\left(Y_{\mathrm{L}}\right.$ and $\left.Y_{S_{n}}\right)$ determined by different methods (see "SEM and image analyses" section). $Y_{\mathrm{L}}$ is based on maximum feldspar size (see Eq. 6 in "SEM and image analyses" section), whereas, the $Y_{S_{n}}$ is derived by total number and area of feldspar crystals (see Eq. 7 in "SEM and image analyses" section) following Brugger and Hammer (2010b)

comparison of XRD semi-quantitative data on whole-rock and related separated shards from each sample indicate comparable mineral phase percentages. This shows that the contribution of phenocrysts is not significant, and XRD data can therefore be used to assess microlite abundance in combination with BSE images.

Generally, pumices are banded, but the individual bands show no significant contortions ( linear). Alkali feldspars are aligned within bands of pumices and, sometimes, clustered in spherulitic clots. The size and abundance of alkali feldspar determined in natural samples allowed us to obtain measurements of CSDs for several samples (Fig. 7). In agreement with previous analysis (D'Oriano et al. 2005; Piochi et al. 2005; Mastrolorenzo and Pappalardo 2006), the size distributions of microlites can be described by two approximately linear trends, a steeper one for crystals smaller than about $0.6 \mathrm{~mm}$,

Table 4 Mineral phase abundances (wt\%) in the Monte Nuovo products as determined by semi-quantitative analyses of the XRD data

\begin{tabular}{lllccc}
\hline Sample & Anorthoclase & Sanidine & Sodalite & Biotite & Magnetite \\
\hline LM C3 wr & 70.9 & 24.8 & 3.4 & 0.6 & 0.4 \\
LM C3 sh & 82.6 & 14.2 & 2.8 & 0.2 & 0.3 \\
LM inf 1 wr & 35.9 & 63.7 & - & 0.5 & - \\
LM inf 1 sh & 34.9 & 64.9 & - & 0.2 & - \\
LM inf d sh & 39.8 & 59.6 & - & 0.5 & 0.1 \\
MN4 wr & 59.5 & 33.6 & 5.8 & - & 1.1 \\
MN4 sh & 54.9 & 39.2 & 5.6 & - & 0.3 \\
\hline
\end{tabular}

Goodness of fit $(\mathrm{GOF})<3$; refer to text for analytical procedures and another, with shallower slope, for larger crystals; trends for different samples are nearly parallel. In comparison, CSDs in the literature (Piochi et al. 2005) show comparable intercept values but smaller crystal sizes as a consequence of using smaller sample areas for CSD measurements; therefore, this should result in under-estimation of the less abundant larger crystals. The stratigraphically lowermost pumices show a simple CSD with a unique growth trend, whereas scoriae are characterized by two trends that suggest two distinct periods of crystal growth (Fig. 7). As a whole, the smaller microlites define CSD curves with slopes that range from -22 to -8 and an intercept at 11 to $19 \mathrm{~mm}^{-4}$, whereas the curves for larger microlites have slopes between -2 and -7 and extrapolated intercepts at $9-11 \mathrm{~mm}^{-4}$ (Table 5). Lower slopes are generally determined for the lower vesicular brownish bands and black scoria (c2s 9-12-1 and MN4 top 06-1, respectively, in Table 5), whereas higher slopes are from the highly vesicular yellow glass.

\section{Discussion}

\section{The role of pressure and $\Delta T$ in changing crystallinity}

By combining our results with those of Arzilli and Carroll (2013), we show that isobaric cooling experiments at 50 and $70 \mathrm{MPa}$ can produce higher $\phi$ than those obtained at 150 and $200 \mathrm{MPa}$ (Fig. 8a, b). Furthermore, the relation between $N_{\mathrm{a}}$ and $\Delta T$ as a function of $P_{\mathrm{f}}$ for cooling experiments (Fig. 8c) shows that at 70 and $100 \mathrm{MPa}, N_{\mathrm{a}}$ increases as $\Delta T$ increases, whereas for experiments at $50 \mathrm{MPa}, N_{\mathrm{a}}$ is more constant with $\Delta T$. The diagram in Fig. $8 \mathrm{~d}$ shows also that $N_{\mathrm{a}}$ is almost constant with time. Our results show that at low $\Delta T, N_{\mathrm{a}}$ increases as $P_{\mathrm{f}}\left(=P_{\mathrm{H}_{2} \mathrm{O}}\right)$ decreases (Fig. 8d), and this indicates that the nucleation process is favored at low pressure, with lower melt $\mathrm{H}_{2} \mathrm{O}$ contents.

In isothermal decompression and decompression + cooling experiments, the high crystallinity textures are produced at 30 and $50 \mathrm{MPa}$ (Fig. 9a, b). Figure 9c shows that $N_{\mathrm{a}}$ for experiments at 30 and $50 \mathrm{MPa}\left(\sim 10^{6.5} \mathrm{~cm}^{-2}\right)$ is $1.5 \log$ unit higher than experiments at 70,100 , and $150 \mathrm{MPa}\left(\sim 10^{5} \mathrm{~cm}^{-2}\right)$ for $\Delta T=40{ }^{\circ} \mathrm{C}$. All experiments have about the same $N_{\mathrm{a}}$ $\left(\sim 10^{5} \mathrm{~cm}^{-2}\right)$ at $\Delta T<40^{\circ} \mathrm{C}$ (Fig. 9c). Probably, small $\Delta T$ could slow down the nucleation process, favoring crystal growth. As with the isobaric cooling results, nucleation of alkali feldspar appears to be strongly favored at lower $P_{\mathrm{f}}$ (Fig. 9d).

The isothermal decompression experiments show the effect of the undercooling (effective undercooling) and pressure $\left(P_{\mathrm{f}}\right)$ on the crystallization kinetics of alkali feldspar (Fig. 10a, b), allowing us to better understand the role of these parameters during magma ascent. Time-temperature-transformation (TTT) diagrams (Fig. 10a) are useful for showing the effect of undercooling and viscosity on transformation kinetics 

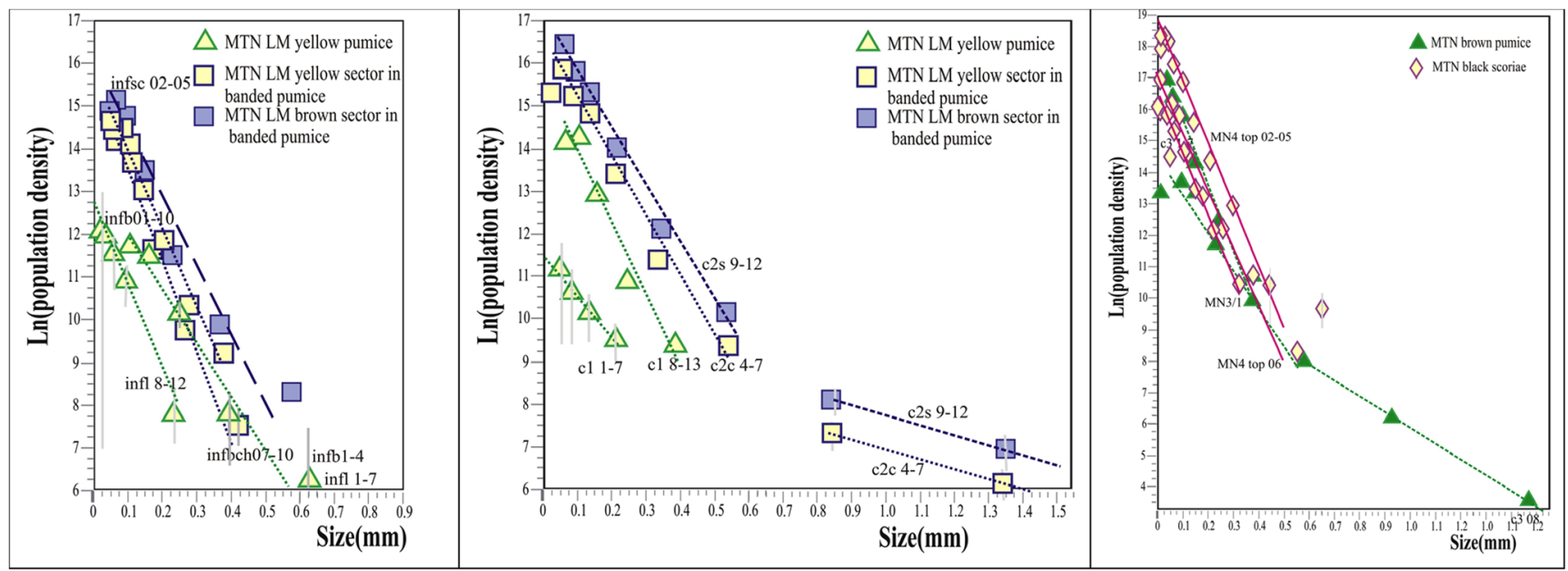

Fig. 7 CSDs of early erupted low-crystalline and highly vesicular pumice (left), brown pumices intermediate in the stratigraphic sequence (central diagram) and scoriae (right diagram). Note the occurrence of two microlite populations and the similarity of slopes for smaller microlites

(Kouchi et al. 1986; Putnis 1992; Porter and Easterling 1997; Hammer and Rutherford 2002; Chevrel et al. 2015). The TTT plot for the crystal fraction variations was determined from the results of the isothermal decompression experiments as a function of $\Delta T, P_{\mathrm{f}}$ and time (Fig. 10a). The crystal fraction $(\phi)$ increases as $\Delta T$ and time increase and $P_{\mathrm{f}}$ decreases
(Fig. 10a). This result can be important for quantifying and modeling crystallization of trachytic magmas in response to magma degassing during ascent in the conduit. Magmas entering shallow volcanic conduits usually contain crystals, and transformation kinetics might be dominated by either feldspar nucleation or growth depending on $\Delta T$-time paths, potentially
Table 5 Crystal growth rates $\left(Y_{\mathrm{L}}\right)$ as derived by experiments and related residence time $\left(t_{\mathrm{r}}\right)$

\begin{tabular}{lrccccc}
\hline Sample & Slope & Intercept $\left(\mathrm{mm}^{-4}\right)$ & $t_{\mathrm{r}}(\mathrm{h})-$ mean & $t_{\mathrm{r}}(\mathrm{h})-\min$ & $t_{\mathrm{r}}(\mathrm{h})-\max$ & $t_{\mathrm{r}}($ days $)$-max \\
\hline infl 8-12 & -20.8 & 12.8 & 6.1 & 1.1 & 121.6 & 5.1 \\
infb 01-10 & -21.6 & 15.7 & 5.8 & 1.1 & 117.2 & 4.9 \\
infl 1-7 & -12.3 & 13.2 & 10.2 & 1.9 & 204.8 & 8.5 \\
infb 1-4 & -15.6 & 16.2 & 8.0 & 1.5 & 161.7 & 6.7 \\
infsc 02-05 & -18.5 & 16.0 & 6.8 & 1.3 & 136.4 & 5.7 \\
infb ch07-10 & -16.1 & 13.3 & 7.8 & 1.4 & 156.5 & 6.5 \\
c1 1-7 & -9.7 & 11.3 & 13.0 & 2.4 & 261.1 & 10.9 \\
c1 8-13 & -17.0 & 15.8 & 7.4 & 1.4 & 148.9 & 6.2 \\
c2c 4-7-1 & -2.3 & 9.3 & 54.7 & 10.1 & 1099.5 & 45.8 \\
c2s 9-12-1 & -2.3 & 10.0 & 55.6 & 10.2 & 1117.4 & 46.6 \\
c2c 4-7-2 & -8.1 & 16.8 & 15.6 & 2.9 & 313.2 & 13.1 \\
c2s 9-12-2 & -13.7 & 17.3 & 9.2 & 1.7 & 184.4 & 7.7 \\
MN4 top 06-1 & -6.7 & 11.0 & 18.9 & 3.5 & 378.8 & 15.8 \\
MN4 top 06-2 & -12.9 & 14.7 & 9.7 & 1.8 & 195.1 & 8.1 \\
c3 1-2 & -19.6 & 16.3 & 6.4 & 1.2 & 128.6 & 5.4 \\
c3 1-2 & -20.4 & 17.5 & 6.2 & 1.1 & 123.7 & 5.2 \\
MN4top 02-05 & -20.0 & 19.0 & 6.3 & 1.2 & 126.3 & 5.3 \\
Experimental growth rate & & mean $Y_{L}=$ & $m a x Y_{L}=$ & $m i n Y_{L}=$ & \\
& & cm/s & $2.21 E-07$ & $1.20 E-06$ & $1.10 E-08$ & \\
& & $m m / h$ & $7.96 E-03$ & $4.32 E-02$ & $3.96 E-04$ & \\
\hline
\end{tabular}

Crystal growth rates $\left(Y_{\mathrm{L}}\right)$ are average of the mean, minimum, and maximum values obtained considering $Y_{\mathrm{L}}$ obtained in this study and from Arzilli and Carroll (2013). Residence times $\left(t_{\mathrm{r}}\right)$ are calculated through the equation: $t_{\mathrm{r}}=\left(-1 / Y_{\mathrm{L}} \times\right.$ slope). Slopes and intercepts as derived by CSD Corrections 1.3 program (Higgins 2000, 2002). CSD diagrams shown in Fig. 7. $t_{\mathrm{r}}$ mean, $t_{\mathrm{r}}$ min, and $t_{\mathrm{r}}$ max are the mean, minimum, and maximum residence times, respectively. Growth rates obtained from experiments are italicized 

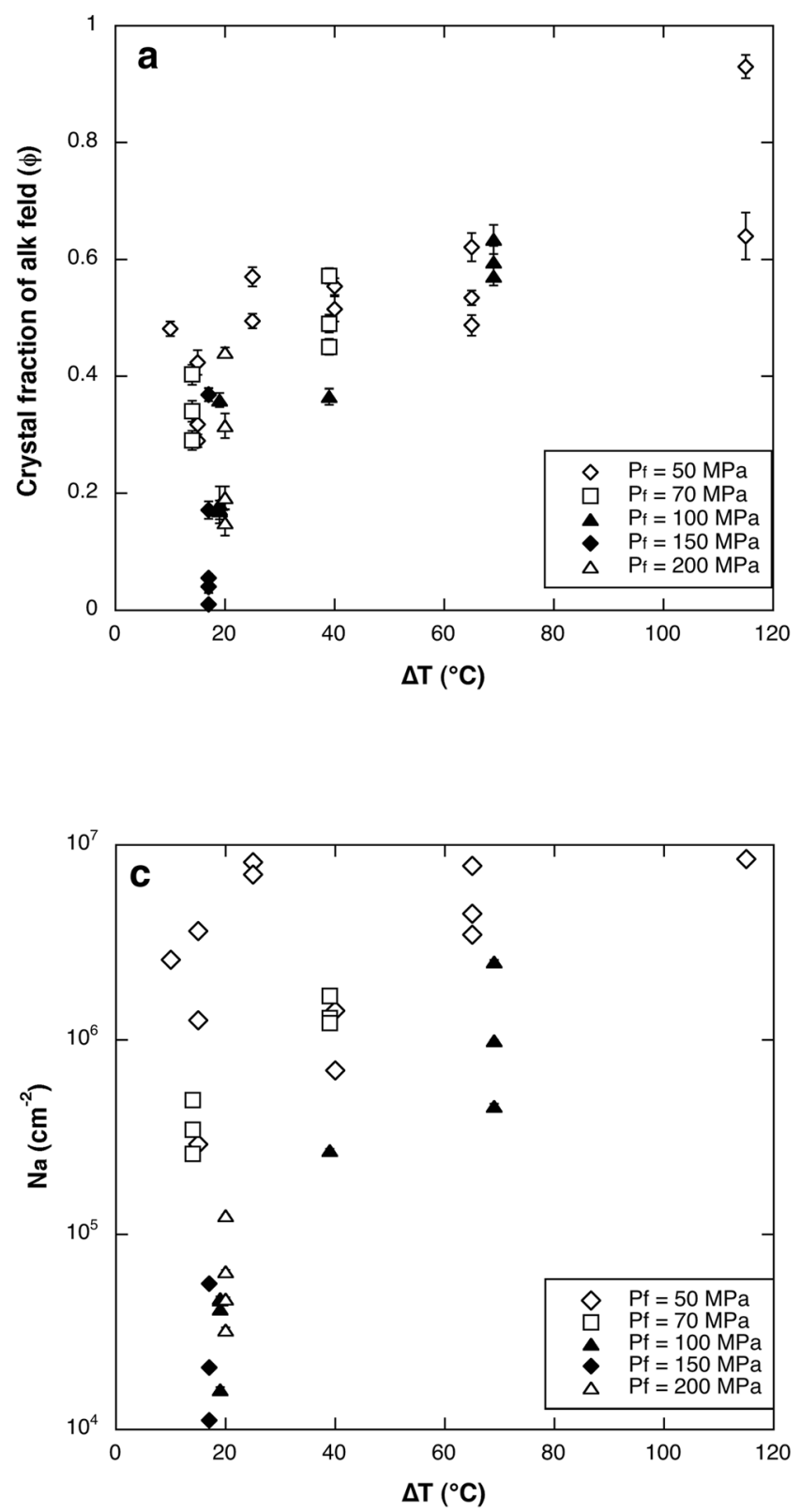

Fig. 8 Textural evolution of alkali feldspar as a function of $\Delta T, P_{\mathrm{f}}$ and $t_{\exp }$ in cooling experiments. a Crystal fraction of alkali feldspar $(\phi)$ as a function of $\Delta T$. b Crystal fraction of alkali feldspar $(\phi)$ as a function of

resulting in large, rapid changes in magma rheology. Figure 10b shows the influence of $\Delta T$ and $P_{\mathrm{f}}$ on nucleation and growth rates at constant time $(1 \mathrm{~h})$, and the results demonstrate that crystal growth is promoted at relatively low $\Delta T$ and high pressure, whereas nucleation rates increase with increasing $\Delta T$ and decreasing pressure (Fig. 10b).

Our results combined with those of Arzilli and Carroll (2013) show that pressure, $\Delta T$, and time can play a fundamental role in controlling the crystallization kinetics of
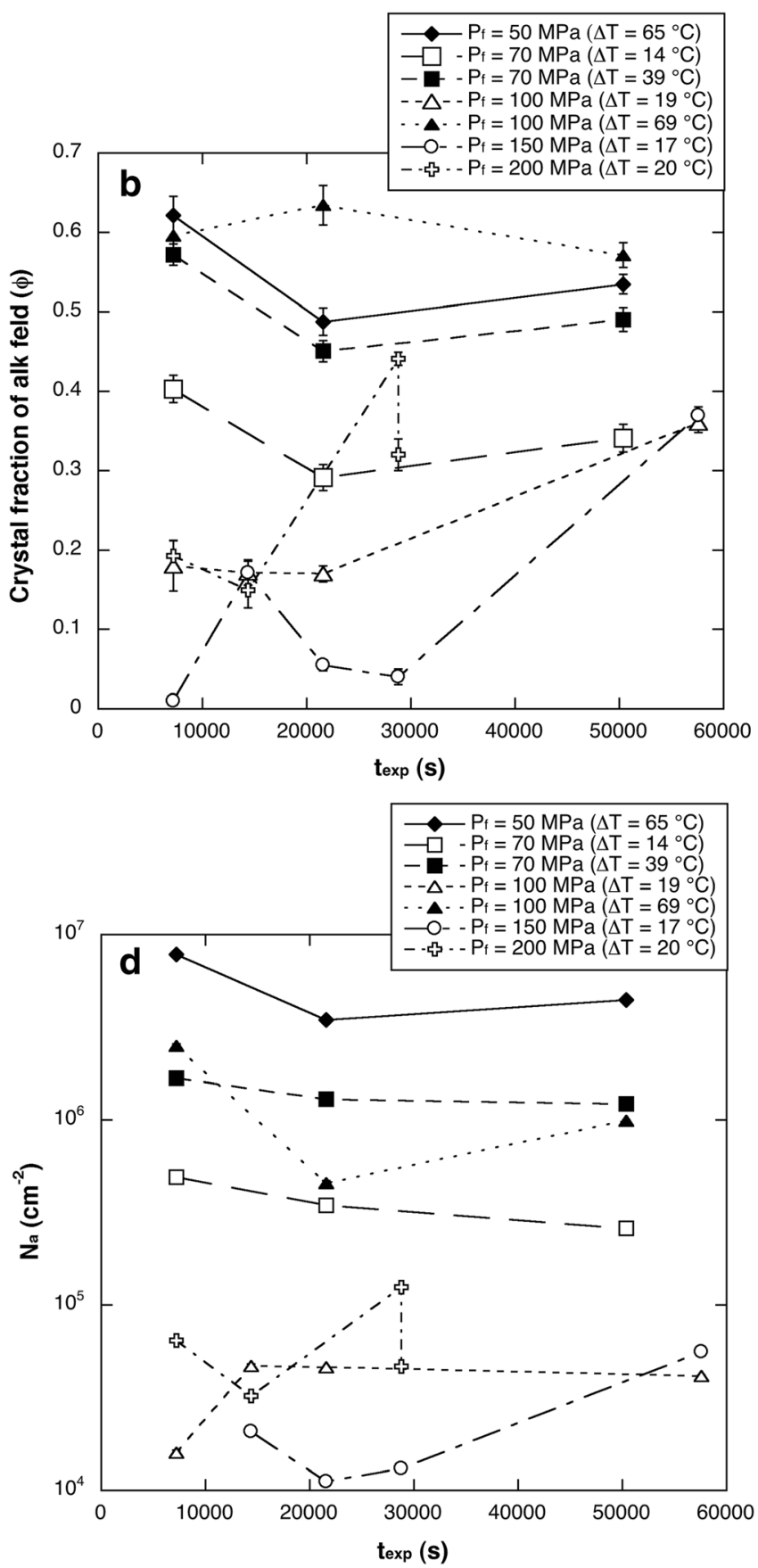

$t_{\text {exp }}$. $N_{\mathrm{a}}$ as a function of $\Delta T$. $\mathbf{d} N_{\mathrm{a}}$ as a function of $t_{\text {exp. Diagrams show }}$ data obtained in this study and from the previous experimental work of Arzilli and Carroll (2013)

trachytic melts. The comparison between isobaric cooling, isothermal decompression, and decompression + cooling experiments shows that similar conditions, in terms of $P_{\mathrm{f}}, \Delta T$, and time, may produce similar $N_{\mathrm{a}}, \phi$, $I_{\mathrm{m}}$ and $Y_{\mathrm{L}}$. This suggests that it is difficult to distinguish between conventional undercooling ( $\Delta T$, related to isobaric cooling) and effective undercooling ( $\Delta T_{\text {eff }}$, related to isothermal decompression) when a single step of cooling and decompression occurs. 

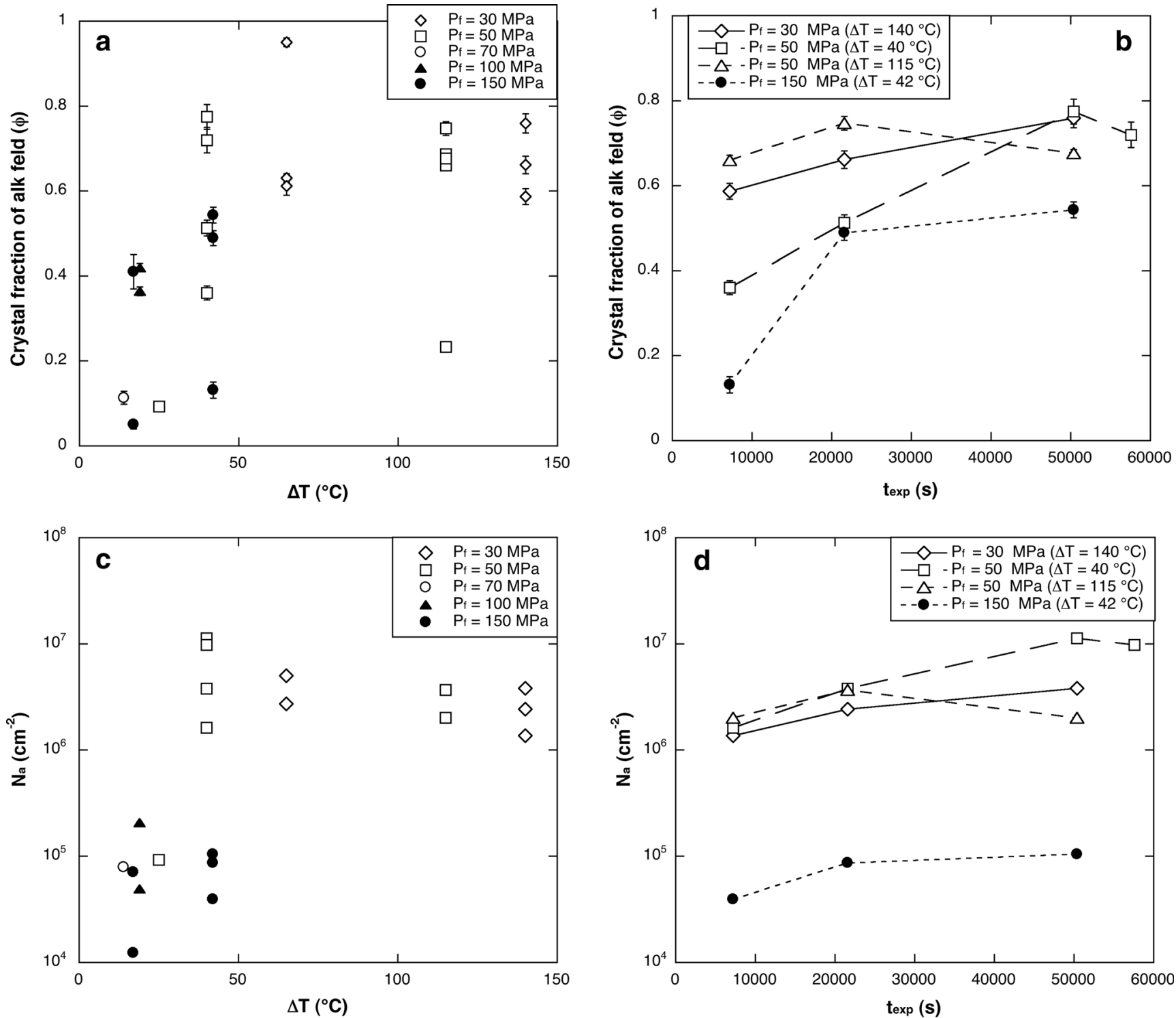

Fig. 9 Textural evolution of alkali feldspar as a function of $\Delta T, P_{\mathrm{f}}$, and $t_{\text {exp }}$ in decompression + cooling and isothermal decompression experiments. a Crystal fraction of alkali feldspar $(\phi)$ as a function of $\Delta T$. b Crystal fraction of alkali feldspar $(\phi)$ as a function of $t_{\text {exp }}$. $\mathbf{c} N_{\mathrm{a}}$ as

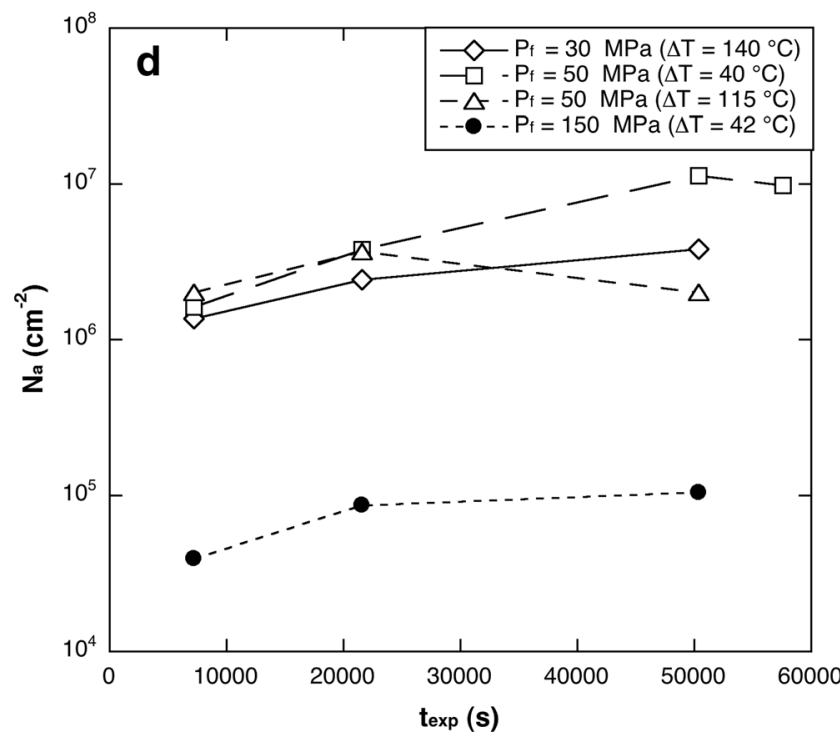

a function of $\Delta T$. $\mathbf{d} N_{\mathrm{a}}$ as a function of $t_{\text {exp }}$. Diagrams show data obtained in this study and from the previous experimental work of Arzilli and Carroll (2013)

The separate effects of pressure and $\Delta T$ on crystallization of alkali feldspar are particularly difficult to distinguish. The main result provided by our combination of isobaric cooling, isothermal decompression, and decompression + cooling experiments is that the nucleation of large numbers of crystals is favored at low $P_{\mathrm{f}}$ (Figs. 4, 8, and 9) and not necessarily only at high $\Delta T$. In fact, for certain conditions of low $P_{\mathrm{f}}$ and low $\Delta T$ (Fig. 9d), nucleation was strongly favored. Our results show that nucleation is reduced at high pressure (Figs, $5,8,9$, and 10b), demonstrating that a dramatic increase of crystal number density can be induced at low pressure in trachytic melts, likely as a result of the effect of

melt $\mathrm{H}_{2} \mathrm{O}$ content on nucleation process, as observed by Hammer (2004) for rhyolitic melts and by Arzilli et al. (2015) for high-K basalts. Furthermore, our results show that the increase of crystallinity and $N_{\mathrm{a}}$ can occur in a few hours (Figs. 8b, d, 9b, d, and 10a). This implies that the rheology of rising trachytic magma could change quickly, affecting the eruptive style.

\section{Magma residence time deduced from growth rates and CSDs}

Measurements of CSD, when combined with experimental growth rate data for alkali feldspar $\left(Y_{\mathrm{L}}\right)$, can help us 

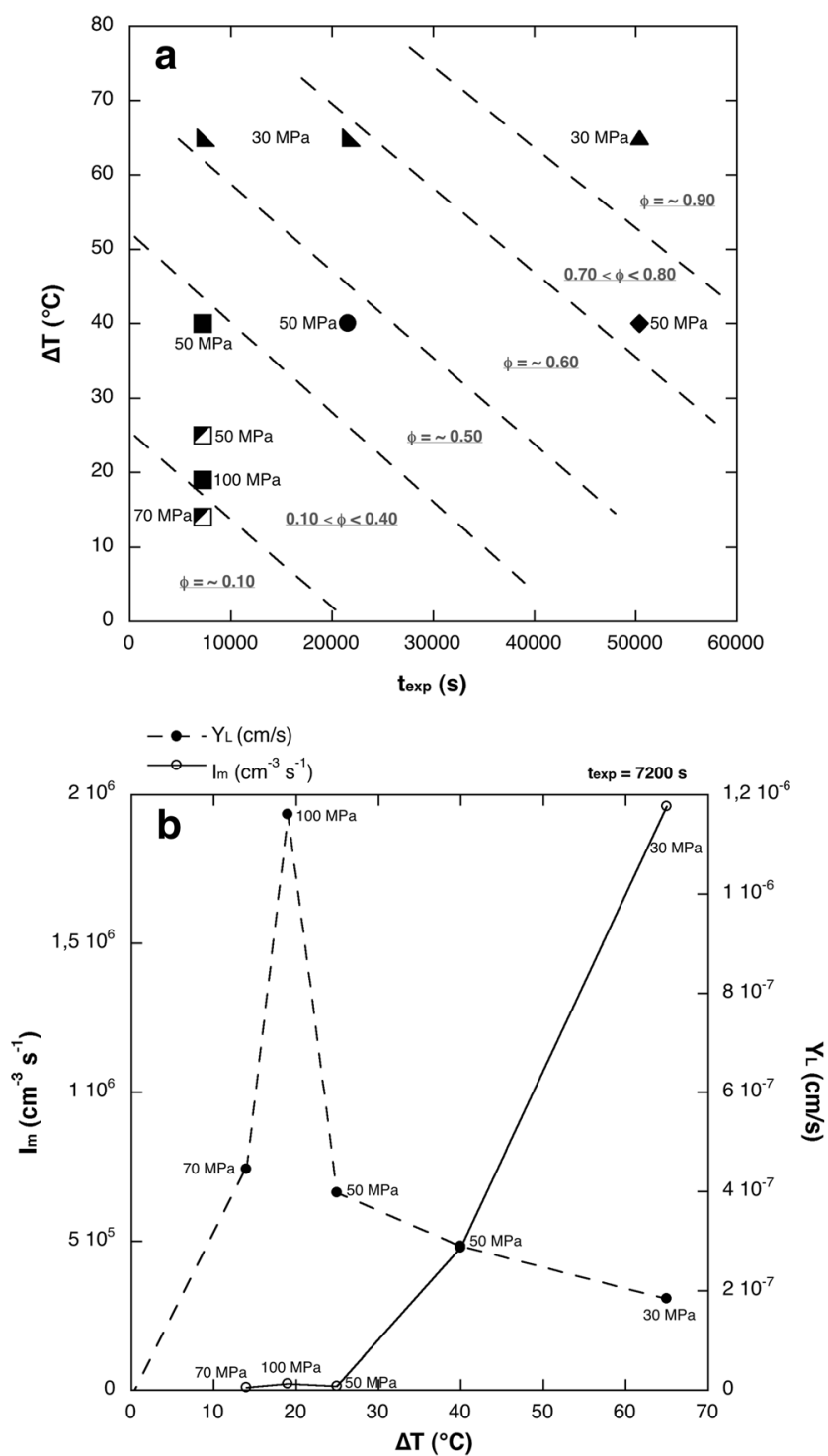

Fig. 10 Crystallization kinetics of isothermal decompression experiments. a Time-temperature-transformation (TTT) diagram constructed using the crystal fraction $(\phi)$ variation as a function of $\Delta T$ and time. $\mathbf{b}$ The variation of nucleation rate $\left(I_{\mathrm{m}}\right)$ and growth rate $\left(Y_{\mathrm{L}}\right)$ with $\Delta T$

to better constrain the time of magma crystallization (e.g., Marsh 1988; Cashman and Marsh 1988; Higgins 1996; Piochi et al. 2005; D’Oriano et al. 2005; Armienti et al. 2007; Brugger and Hammer 2010a). The empirical approach is largely used by geologists and engineers, although different assumptions must be met (Eberl et al. 1998, 2002; Brugger and Hammer 2010a). A batch crystallization mechanism in which no mass was added or subtracted to the crystallizing system is required (e.g., Marsh 1988). This assumption is satisfied by the homogeneous mineral assemblage, the proportion of phases, and the chemical composition of natural products (Piochi et al. 2005, 2008), related to each deposit of Monte Nuovo. Furthermore, sizeproportionate growth of crystals, which has been largely observed and modeled in low-viscosity aqueous solutions (Eberl et al. 1998, 2002; Kile and Eberl 2003), must be excluded. Therefore, the considerations above support the assumption of (approximately) constant growth rate and variable nucleation rate through time in viscous magmas. In addition, the textural similarities (in both $N_{\mathrm{a}}$ and $\phi$ ) between synthetic and natural samples (Fig. 11) could indicate the main role of pressure on nucleation rate and decompression of magma as the dominant processes during the Monte Nuovo eruption. The increase of $\phi$ and $N_{\mathrm{a}}$ through experimental time (Figs. 9b and 10a) could definitively affect the CSDs. However, the concave-up CSD patterns could be an artifact caused by the presence of two populations, in line with previous works (Piochi et al. 2005 and D'Oriano et al. 2005) and experiments (Brugger and Hammer 2010a).

We use new data on both CSDs (Fig. 7) and feldspar growth rates to make new estimates of crystallization times $\left(t_{\mathrm{r}}\right)$ for the Monte Nuovo magma (Table 5). The estimated growth rates $\left(Y_{\mathrm{L}}\right)$ mostly vary between $1.1 \times 10^{-8}$ and $7.2 \times 10^{-7} \mathrm{~cm} / \mathrm{s}$, with one higher value at $1.2 \times 10^{-6} \mathrm{~cm} / \mathrm{s}$, and the mean $Y_{L}$ equal to $2.21 \times 10^{-7} \mathrm{~cm} / \mathrm{s}$ (Table 5). Since $Y_{\mathrm{L}}$ is slightly higher than $Y_{S_{n}}$ (Fig. 6), we used the former as it is the maximum growth rate, and therefore, it allows us to estimate the lower limit on the timescale of the magma residence. The variation of magma residence time (Table 5) is related to the range of growth rates and CSD slopes, and estimated crystal growth timescales range from few months to few hours. The mean $Y_{\mathrm{L}}$ (here the mean $Y_{\mathrm{L}}$ is considered the most representative growth rate) and the CSD slopes suggest that magma was stored for a few days in the subsurface (obtained from the flatter CSD slopes) and the ascent up to quenching lasted a few hours (obtained from the steep CSD slopes) (see Fig. 7 and Table 5). These residence times appear realistic when compared with timing of phenomena observed prior to eruption (see "The Monte Nuovo eruption" section; Fig. 1). Notably, the steep CSD slopes (i.e., correspond to short residence times) characterize the early erupted sodalitefree pumices, indicating the abrupt quenching of magma rising from the deeper levels. The flatter CSD slopes (i.e., correspond to long residence times) characterize the most crystalline matrices, in which the anorthoclase is more abundant than sanidine in scoriae and brown pumices (Table 4).

\section{Implication for magma dynamics during the Monte Nuovo eruption}

Experimental alkali feldspars have elongated rectangular crystal shapes, and they occur in clots (Fig. 4) or isolated in the glass (Fig. 5), similar to their occurrence in 

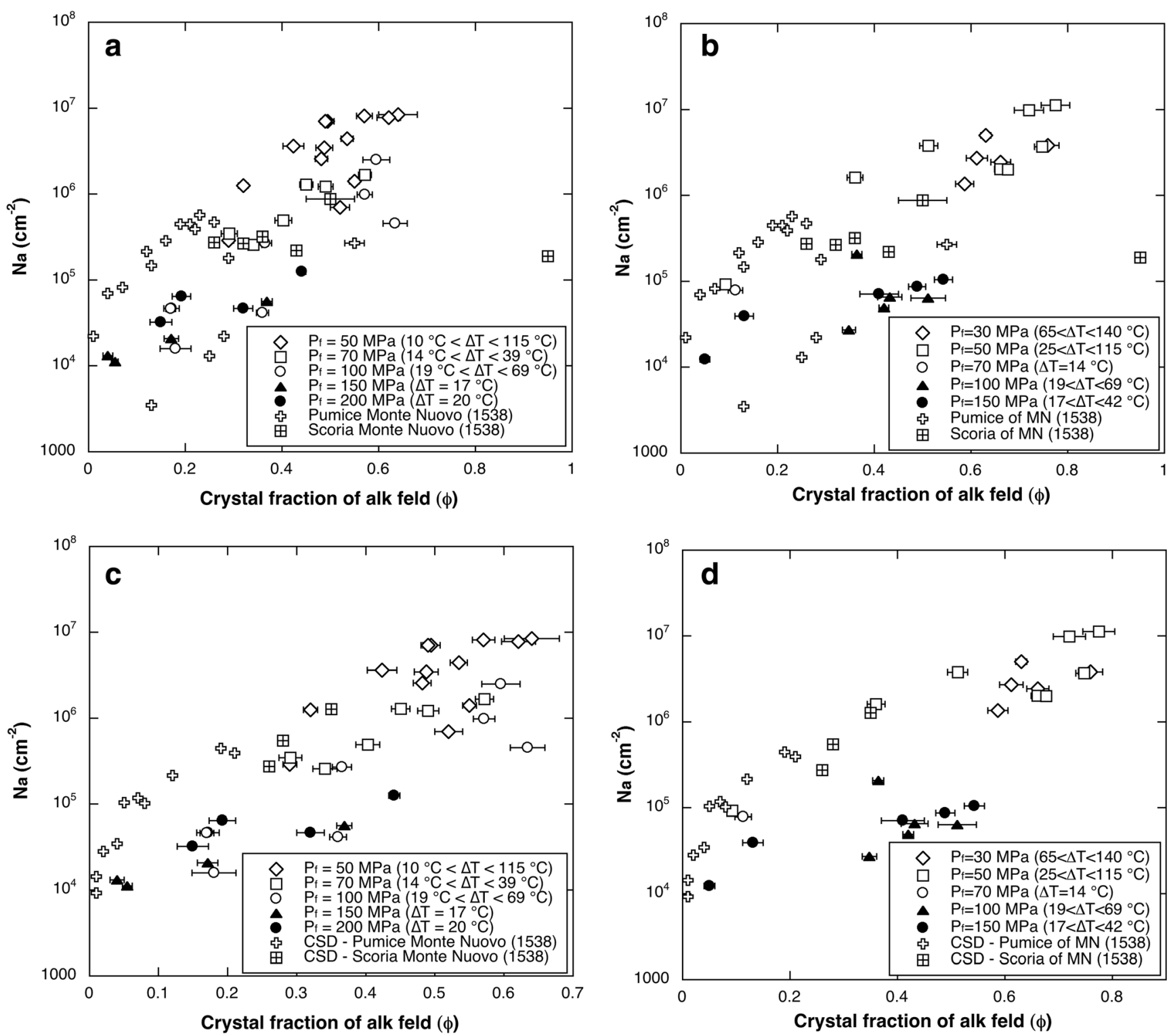

Fig. 11 Textural evolution of alkali feldspar as a function of $\Delta T$ and $P_{\mathrm{f}}$. Textural evolution of alkali feldspar in isobaric cooling (a), (c) and, in isothermal decompression and decompression + cooling (b), (d) experiments, compared with that in natural samples of Monte Nuovo (pumices and scoriae). a, b The nucleation density $\left(N_{\mathrm{a}}\right)$ and the crystal fraction $(\phi)$ of alkali feldspar were obtained from batch calculation. $\mathbf{c}, \mathbf{d}$

$N_{\mathrm{a}}$ and $\phi$ of cooling and decompression experiments were obtained from batch calculation, whereas $N_{\mathrm{a}}$ and $\phi$ of natural samples of Monte Nuovo were obtained from CSD results. Diagrams show data obtained in this study and from the previous experimental work of Arzilli and Carroll (2013)

the natural pumices (Fig. 3). Both isothermal decompression and decompression + cooling experiments at $50 \mathrm{MPa}$ produced textures similar to those of natural scoriae, with high crystallinity and aligned tabular or elongated rectangular crystals (see Figs. $3 \mathrm{~b}$ and $5 \mathrm{c}$ ), together with magnetite and sodalite crystals (Table 4). The highly crystalline samples also show vesicles with irregular margins similar to the natural scoriae. Furthermore, the Or content of the synthetic alkali feldspars and those of natural ones is similar, ranging between 40 and $70 \mathrm{~mol} \%$ (D'Oriano et al. 2005; Piochi et al. 2005; Piochi et al. 2008). The experiments

produced material texturally comparable with the natural products, although the pyroxene occurrence, albeit not abundant $(<0.10)$, represents the most important discrepancy. This may depend on the starting experimental conditions because pyroxenes are present in the ZAC starting material, and the oxygen fugacity of the CSPV $(\sim \mathrm{NNO}+1 \log$ units) may also be different from that of the Monte Nuovo system.

Decompression (isothermal decompression and decompression + cooling) experiments show two populations with different nucleation density (Fig. 11b, d). The first population at low pressure $\left(30 \mathrm{MPa}<P_{\mathrm{f}}<50 \mathrm{MPa}\right)$ has values of $N_{\mathrm{a}}$ 
between $10^{6}$ and $10^{7} \mathrm{~cm}^{-2}$, exceeding values observed in the natural samples (Fig. 11b, d). The second group of experiments at high pressures $\left(100 \mathrm{MPa}<P_{\mathrm{f}}<150 \mathrm{MPa}\right)$ has values of $N_{\mathrm{a}}$ between $10^{4}$ and $10^{5} \mathrm{~cm}^{-2}$, similar to the poorly crystallized pumice (Fig. 11b, d). Instead, $\phi$ ranges from $\sim 0.10$ to $\sim 0.60$, showing values similar to and higher than those of natural pumices (Fig. 11b, d). The experiments at $50 \mathrm{MPa}$ (sample D81), $70 \mathrm{MPa}$ (sample D82), $100 \mathrm{MPa}$ (sample D80), and $150 \mathrm{MPa}$ (sample D55) are characterized by $N_{\mathrm{a}}=\sim 10^{5} \mathrm{~cm}^{-2}$ and $\phi$ between $\sim 0.10$ and $\sim 0.30$ (Arzilli and Carroll 2013), therefore comparable with poorly crystallized natural pumice (Fig. 11b, d). Isothermal decompression experiments show that the crystallinity of natural samples could increase during magma ascent, because the increase of $\Delta T$ and time and the decrease of pressure produce an increase of $\phi$ (Fig. 10a). Furthermore, the increasing number of crystals with small size in scoriae (Fig. 7) could be related to the increase of $I_{\mathrm{m}}$ with $\Delta T$ (low pressure) (see Fig. 10b). In fact, the comparison between experimental nucleation rates and those obtained from CSD suggests that the main crystallization of the scoriae occurred from 50 to $30 \mathrm{MPa}$ (Fig. 12a). The $\phi$ of alkali feldspar $=0.01-0.30$ in the pumices implies $\Delta T<50{ }^{\circ} \mathrm{C}$ and $P>70 \mathrm{MPa}$; the increase in $\phi$ up to 0.40 0.60 in the scoriae, as well as the highest one at 0.95 (D'Oriano et al. 2005), requires higher $\Delta T$ and low pressure.

The experimental results suggest that the crystallization of alkali feldspars in magma erupted during the Monte Nuovo eruption started between $<200$ and $100 \mathrm{MPa}$ when temperature was close to the liquidus of alkali feldspar $\left(825-840{ }^{\circ} \mathrm{C}\right.$ ) (see Fig. 1 in Arzilli and Carroll 2013). This is also supported by the low amount of biotite in natural products (Table 4); in fact, previous experimental work and the present results (see samples D20, D15, D17, D25 in Tables 1 and 2) on trachytic melts indicate the stability field of biotite at pressure $>135 \mathrm{MPa}$ (Fabbrizio and Carroll 2008). Based on these results, we constrain the pre-eruptive magma storage at a depth consistent with biotite crystallization $(>4 \mathrm{~km}$ ), slightly deeper than hypothesized by Piochi et al. (2005). Furthermore, our experimental data indicate that the early erupted Monte Nuovo magma (LM unit) stayed at 30-50 MPa ( $2 \mathrm{~km}$ of depth) for only a short time. Sodalite absence and biotite occurrence in these samples support such barometric conditions. Low $\Delta T$ can be suggested for the early erupted products, supporting previous inferences (D'Oriano et al. 2005). Our results indicate lower pressures for the later erupted magma (i.e., scoriae in the Upper Member) registers. The high groundmass crystallinity with alkali feldspar as the dominant phase and the sodalite occurrence in these later erupted fragments (Table 4) suggest effective undercoolings of several hundreds degrees Celsius and pressure of crystallization below $50 \mathrm{MPa}$ (see Tables 2 and 3). The sodalite occurrence should be due to the high
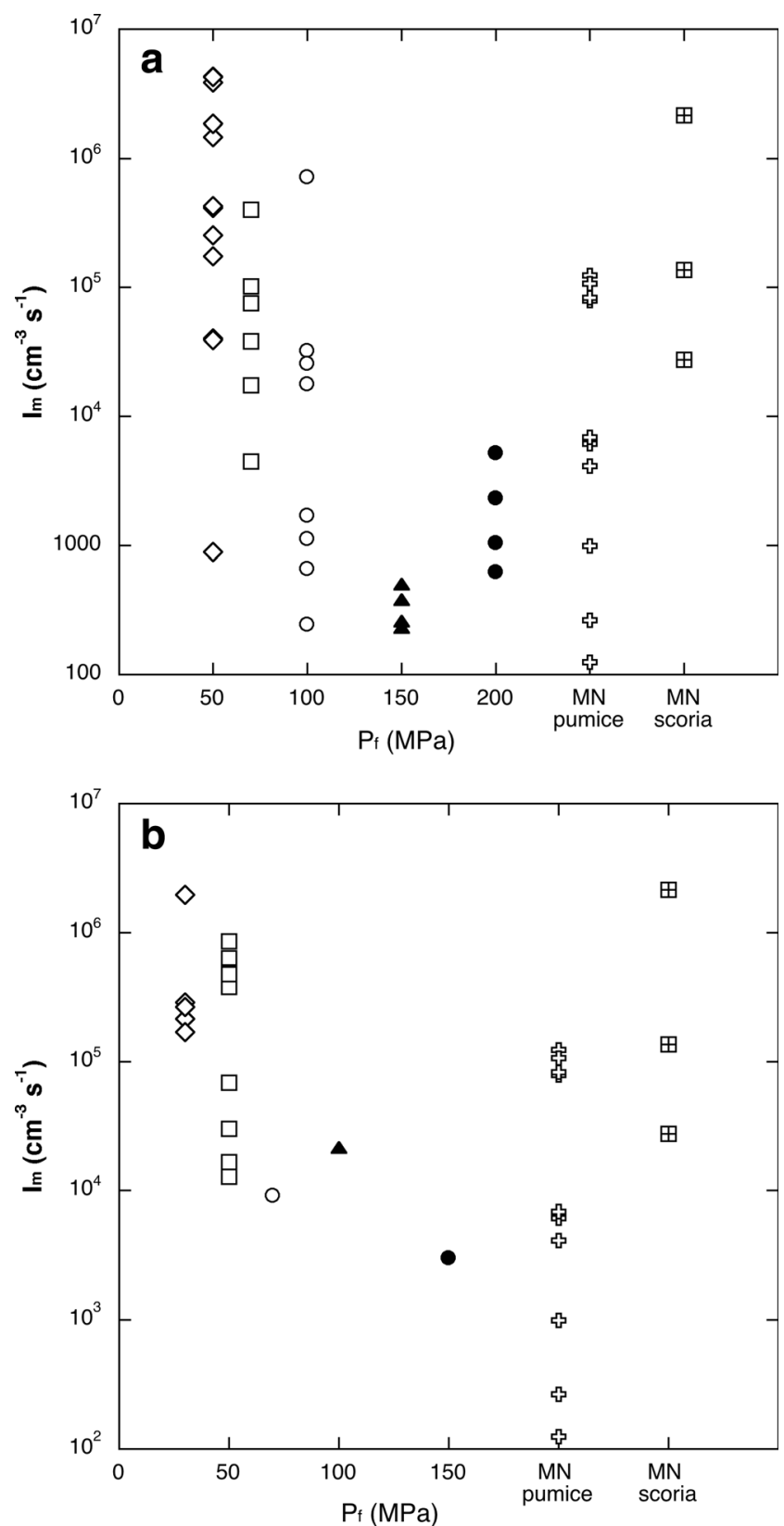

Fig. 12 Comparison between experimental nucleation rates $\left(I_{\mathrm{m}}\right)$ and those obtained from CSD results. a The diagram reports $I_{\mathrm{m}}$ obtained from cooling experiments and from CSD results of pumices and scoriae of Monte Nuovo $(\mathrm{MN})$. b) The diagram reports $\mathrm{I}_{\mathrm{m}}$ obtained from isothermal decompression and decompression + cooling experiments and from CSD results of pumices and scoriae of Monte Nuovo $(M N)$

crystallinity and the enrichment of $\mathrm{Cl}$ in the residual melt that occurs at low pressure (Carroll 2005). This is in agreement with the content of $\mathrm{Cl}$ in brown pumices and scoriae, which is relatively higher than that of other pumices (Piochi et al. 2008). Decompression was the main process controlling the textures of the Monte Nuovo products, in agreement with occurrence of microlites that are curved following the morphology of adjacent vesicles, suggesting that they grew concomitantly with vesicles (Piochi et al. 
2005, 2008). In particular, our results support the idea that decompression and a decrease in $\mathrm{H}_{2} \mathrm{O}$ solubility promoted extensive crystallization in later erupted magma (Fig. 3), moving the melt towards the most evolved trachyte compositions observed (D'Oriano et al. 2005; Piochi et al. 2008)

Magma ascent from the storage depths $(\leq 135 \mathrm{MPa})$ to shallower depths ( $\leq 50 \mathrm{MPa}$ ) occurred rapidly, with timescales on the order of hours suggested by our CSD results (see Table 5). Fabbrizio and Carroll (2008) also suggested that the travel of the biotite-bearing phlegraean magma from reservoir at depth of c. $7 \mathrm{~km}(\sim 200 \mathrm{MPa})$ to the surface was rapid, based on dissolution rate data of biotites (hours to a maximum of 1-2 days; Fabbrizio and Carroll 2008). Low ascent rate results in dissolution of biotite. Therefore, the magma ascent rate is estimated in $400-100 \mathrm{~m} / \mathrm{h}$ from a depth of $4-5 \mathrm{~km}$ (biotite-stable). Magma storage of some days in the shallow crust is indicated by the occurrence of some phenocrysts (that define CSD slope $>-10$, Table 5, Fig. 7), whereas the smallersized crystals (and the CSD with steeper slopes; Table 5 and Fig. 7) were able to crystallize in a few hours. These results better constrain previous reconstruction of this eruption (Piochi et al. 2005; D'Oriano et al. 2005) and suggest the utility of similar studies for assessment of volcanic hazards. The detected CSD variation reflects the textural features of samples, resulting from small differences in rates of magma ascent, crystallization, and degassing (see also D'Oriano et al. 2005; Piochi et al. 2005, 2008) during eruption. The LM vesicular pumices (early erupted; Fig. 1) register the magmatic fragmentation generated by magma-water interaction following gas expansion, while syn-eruptive outgassing-induced crystallization produced brown pumices and scoriae (later erupted magma; Fig. 1) in the course of the eruption. The most crystalline and less vesicular scoriae contain a lower amount of $\mathrm{H}_{2} \mathrm{O}$ than LM microlite-poor and vesicle-rich pumices (Piochi et al. 2008).

The phlegraean trachyte can rapidly crystallize large crystal fractions of alkali feldspar, over small pressure-temperature intervals (Figs. 10, 11, and 12), and this can strongly modify the rheology of a trachytic magma, favoring rapid changes in eruptive style or ending of the eruption. Our results allow us to constrain the processes producing the change in eruptive style from pumice to scoria type deposits due to an increase of magma viscosity (Caricchi et al. 2008; Vona et al. 2011), quantitatively supporting the idea of D'Oriano et al. (2005) about plug generation in the volcanic conduit in the last eruptive phase. In fact, values of $\phi$ between 0.80 and $0.90 \mathrm{ob}-$ served in the natural scoriae of Monte Nuovo produced in this phase requires higher $\Delta T$ and lower $P$, as suggested from the experiments. The abundance of crystals in the scoria deposits reaching values higher than $90 \%$ (Fig. 11a, b; D'Oriano et al. 2005) may be related to high $\Delta T$ and low $P_{\mathrm{f}}$ or longer residence of the magma in a shallower part $\left(P_{\mathrm{f}}<50 \mathrm{MPa}\right)$ of the conduit (the crystallization in the brown pumice and scoriae occurred over a longer time compared with pumice sample crystallization), as shown from our results (see samples D69, D78, and D62). Increased $\Delta T$ can enhance crystal formation by increasing crystal nucleation rate (Fig. 10), changing the magma rheology toward more viscous behavior as crystal content increases. Furthermore, Melnik (2000) shows that the high viscosity of the magma in the conduit is probably responsible for increasing pressurization, and our results justify a potential overpressure in the conduit, which may have triggered the final vulcanian explosion of Monte Nuovo.

Finally, the coexistence of pumices with different vesicle and microlite textures (for example, samples LM inf 1, LM in $\mathrm{d}$, and LM c3) suggests a complex process of magma ascent. Mingling between magmas that reached the surface through different pathways and pressure-temperature-time conditions in the subsurface or lateral variations of magma conditions in the conduit (D'Oriano et al., 2005) are possibilities to be further investigated.

\section{Conclusions}

The comparison between experimental data and natural data provides a set of $\mathrm{P}-\mathrm{T}-\mathrm{H}_{2} \mathrm{O}$ content conditions for trachytic magmas valid for the Monte Nuovo eruption at Campi Flegrei. The cooling and decompression experiments reproduced textures observed in pumices and scoriae produced during the $1538 \mathrm{AD}$ eruption. Our results indicate that the juvenile pyroclastic components provide a record of magma ascent conditions within the volcanic conduit. This eruption requires a water-saturated magma stored at around 150$135 \mathrm{MPa}$, near the liquidus temperature of alkali feldspar; its ascent toward the surface lasted a few hours to several days. Our results do not furnish direct information concerning what triggered the eruption at Monte Nuovo.

As a whole, this experimental study offers a set of pressure, temperature, and undercooling (water-saturated) conditions, useful to constrain the timescale and to better understand the magma behavior of numerous phlegraean eruptions, using the textures of their trachy-phonolitic products. In fact, alkali feldspar is the main crystal phase in the phlegraean rocks and, as shown for the Monte Nuovo eruption, its crystallization could be occurred between 4 and $7 \mathrm{~km}$ depth ( 100-200 MPa) and proceed at shallow depths, where the magma ascent through the conduit was faster and texture was effectually frozen in (mostly between 2 and $3 \mathrm{~km} ; 50-70 \mathrm{MPa}$ ). The absence of sodalite in most of the natural samples implies a rapid magma ascent at $30-50 \mathrm{MPa}$ (pressure for sodalite stability) or magmas stored at these levels only occasionally were erupted. Furthermore, the temperature of the magma, in pre-eruptive conditions, is most likely between 825 and $840{ }^{\circ} \mathrm{C}$ (close to the liquidus of alkali feldspar). 
Acknowledgments This work was supported by the 2005-2006 INGV-DPC project V3-2/UR14 (M. Piochi) and PRIN 2009 (R. Moretti), FAR 2012, and PRIN 2009 (M. R. Carroll). We warmly thank the Associate Editor P. J. Wallace for careful handling of the manuscript and for useful corrections and comments that have substantially improved it. The authors acknowledge C. Martel and an anonymous reviewer for the detailed and constructive comments that greatly helped the authors in improving the manuscript. We are grateful to N. Cennamo (II University of Napoli, Naples, Italy) for help with the BSE image acquisition and Luigi Zeni (II University of Napoli, Naples, Italy) that allowed access to the laboratory. The VULCAMED project provided funds to install in October 2012 the XRD laboratory at the Istituto Nazionale di Geofisica e Vulcanologia, in Naples. We would like to thank P. Scarlato, C. Freda, and A. Cavallo for assistance with the SEM at INGV, Rome. We warmly thank M. W. Schmidt for providing SEM access at ETH of Zurich (Institute of Geochemistry and Petrology). We also thank P. Landi for SEM analysis and M. R. Cicconi for assistance during experiments.

Open Access This article is distributed under the terms of the Creative Commons Attribution 4.0 International License (http:// creativecommons.org/licenses/by/4.0/), which permits unrestricted use, distribution, and reproduction in any medium, provided you give appropriate credit to the original author(s) and the source, provide a link to the Creative Commons license, and indicate if changes were made.

\section{References}

Abramoff MD, Magalhaes PJ, Ram SJ (2004) Image processing with Image J. Biophoton Int 11:36-42

Armienti P, Francalanci L, Landi P (2007) Textural effects of steady state behaviour of the Stromboli feeding system. J Volcanol Geoth Res 160:86-98

Arzilli F, Carroll MR (2013) Crystallization kinetics of alkali feldspars in cooling and decompression-induced crystallization experiments in trachytic melt. Contrib Mineral Petrol 166:1011-1027

Arzilli F, Agostini C, Landi P, Fortunati A, Mancini L, Carroll MR (2015) Plagioclase nucleation and growth kinetics in a hydrous basaltic melt by decompression experiments. Contrib Mineral Petrol 170: $1-16$

Boivin P, Bourdier JL, Camus G, de Goer de Herve A, Gourgaud A, Kieffer G, Mergoil JM, Vincent PM, Auby R (1982) Influence de la Nature des Magmas sur l'Activité Phreatomagmatique: Approche Volcanologique et Thermodynamique. Bull Volcanol 45:25-39

Brugger CR, Hammer JE (2010a) Crystal size distribution analysis of plagioclase in experimentally decompressed hydrous rhyodacite magma. Earth Planet Sci Lett 300:246-254

Brugger CR, Hammer JE (2010b) Crystallization kinetics in continuous decompression experiments: implications for interpreting natural magma ascent processes. J Petrol 51:1941-1965

Calzolaio M, Arzilli F, Carroll MR (2010) Growth rate of alkali feldspars in decompression-induced crystallization experiments in a trachytic melt of the Phlegraean Fields (Napoli, Italy. Eur J Mineral 22:485493

Caricchi L, Giordano G, Burlini L, Ulmer P, Romano C (2008) Rheological properties of magma from the 1538 eruption of Monte Nuovo (Phlegrean Fields, Italy): an experimental study. Chem Geol 256:158-171

Carroll MR (2005) Chlorine solubility in evolved alkaline magmas. An Geophys 48:619-631

Carroll MR, Blank JG (1997) The solubility of $\mathrm{H}_{2} \mathrm{O}$ in phonolitic melts. Am Mineral 82:549-556
Cashman KV, Marsh BD (1988) Crystal size distribution (CSD) in rocks and the kinetics and dynamics of crystallization II: Makaopuhi lava lake. Contrib Mineral Petrol 99:292-305

Cheng HC, Lemlich R (1983) Errors in the measurement of bubble size distribution in foam. Ind Eng Chem Fundam 22:105-109

Chevrel MO, Cimarelli C, deBiasi C, Hanson JB, Lavallee Y, Arzilli F, Dingwell DB (2015) Viscosity measurements of crystallizing andesite from Tungurahua volcano (Ecuador. Geochem Geophys Geosyst $16: 870-889$

Couch S (2003) Experimental investigation of crystallization kinetics in a haplogranite system. Am Miner 88:1471-1485

Couch S, Sparks RSJ, Carroll MR (2003) The kinetics of degassinginduced crystallization at Soufriere Hills volcano, Montserrat. J Petrol 44:1477-1502

D’Oriano C, Poggianti E, Bertagnini A, Cioni R, Landi P, Polacci M, Rosi $M(2005)$ Changes in eruptive style during the A.D. 1538 Monte Nuovo eruption (Phlegrean Fields, Italy): the role of syn-eruptive crystallization. Bull Volcanol 67:601-621

Del Gaudio C, Aquino I, Ricciardi GP, Ricco C, Scandone R (2010) Unrest episodes at Campi Flegrei: a reconstruction of vertical ground movements during 1905-2009. J Volcanol Geotherm Res 195:48-56

Di Matteo V, Carroll MR, Behrens H, Vetere F, Brooker R (2004) Water solubility in trachytic melts. Chem Geol 213:187-196

Di Renzo V, Arienzo I, Civetta L, D’Antonio M, Tonarini S, Vito MD, Orsi G (2011) The magmatic feeding system of the Campi Flegrei caldera: architecture and temporal evolution. Chem Geol 281:227241

Di Vito MA, Isaia R, Orsi G, Southon J, de Vita S, D'Antonio M, Pappalardo L, Piochi M (1999) Volcanism and deformation since 12,000 years at the Campi Flegrei caldera (Italy. J Volcanol Geoth Res 91:221-246

Di Vito M, Lirer L, Mastrolorenzo G, Rolandi G (1987) The 1538 Monte Nuovo eruption (Campi Flegrei, Italy. Bull Volcanol 49:608-615

Dobson PF, Epstein S, Stolper EM (1989) Hydrogen isotope fractionation between coexisting vapor and silicate glasses and melts at low pressure. Geochim Cosmochim Acta 53:2723-2730

E berl DD, Drits VA, Srodon J (1998) Deducing growth mechanisms for minerals from the shapes of crystal size distributions. Am J Sci 298: 499-533

Eberl DD, Kile DE, Drits VA (2002) On geological interpretations of crystal size distributions: constant vs. proportionate growth. Am Mineral 87:1235-1241

Fabbrizio A, Carroll MR (2008) Experimental constraints on the differentiation process and pre-eruptive conditions in the magmatic system of Phlegraean Fields (Naples, Italy. J Volcanol Geoth Res 171: $88-102$

Fedele L, Scarpati C, Lanphere M, Melluso L, Morra V, Perrotta A, Ricci G (2008) The Breccia Museo formation, Campi Flegrei, southern Italy: geochronology, chemostratigraphy and relationship with the Campanian Ignimbrite eruption. Bull Volcanol 70:1189-1219

Fenn PM (1977) The nucleation and growth of alkali feldspars from hydrous melts. Can Mineral 15:135-161

Geschwind C, Rutherford MJ (1995) Crystallization of microlites during magma ascent: the fluid mechanics of 1980-1986 eruptions at Mount St Helens. Bull Volcanol 57:356-370

Guidoboni E, Ciuccarelli C (2011) The Campi Flegrei caldera: historical revision and new data on seismic crises, bradyseisms, the Monte Nuovo eruption and ensuing earthquakes (twelfth century 1582 AD. Bull Volcanol 73:655-677

Hammer JE (2004) Crystal nucleation in hydrous rhyolite: experimental data applied to classical theory. Am Mineral 89: $1673-1679$

Hammer JE, Rutherford MJ (2002) An experimental study of the kinetics of decompression-induced crystallization in silicic melt. J Geophys Res 107:2021 
Hammer JE, Cashman KV, Hoblitt RP, Newman S (1999) Degassing and microlite crystallization during pre-climactic events of the 1991 eruption of Mt. Pinatubo, Philippines. Bull Volcanol 60:355-380

Higgins MD (1996) Magma dynamics beneath Kameni volcano, Thera Greece, as revealed by crystal size and shape measurements. J Volcanol Geoth Res 70:37-48

Higgins MD (2000) Measurements of crystal size distributions. Am Mineral 85:1105-1116

Higgins MD (2002) Closure in crystal size distributions (CSD), verification of CSD calculations, and the significance of CSD fans. Am Mineral 87:171-175

Iezzi G, Mollo S, Ventura G, Cavallo A, Romano C (2008) Experimental solidification of anhydrous latitic and trachytic melts at different cooling rates: the role of nucleation kinetics. Chem Geol 253:91101

Isaia R, Marianelli P, Sbrana A (2009) Caldera unrest prior to intense volcanism in Campi Flegrei (Italy) at 4.0 ka B.P.: implications for caldera dynamics and future eruptive scenarios. Geophys Res Lett 36 L21303

Kile DE, Eberl DD (2003) On the origin of size-dependent and sizeindependent crystal growth: influence of advection and diffusion. Am Mineral 88:1514-1521

Kouchi A, Tsuchiyama A, Sunagawa I (1986) Effect of stirring on crystallization kinetics of basalt: texture and element partitioning. Contrib Mineral Petrol 9:429-438

La Spina G, Burton M, de' Michieli Vitturi M (2015) Temperature evolution during magma ascent in basaltic effusive eruptions: A numerical application to Stromboli volcano. Earth Planet Sci Lett 426:89 100

Le Bas MJ, Le Maitre RW, Streckeisen A, Zanettin B (1986) A chemical classification of volcanic rocks based on the total alkali-silica diagram. J Petrol 27:745-750

Lirer L, Luongo G, Scandone R (1987) On the volcanological evolution of Campi Flegrei. Eos Trans AGU 68

Marsh BD (1988) Crystal size distribution (CSD) in rocks and the kinetics and dynamics of crystallization. Contrib Mineral Petrol 99:277-291

Marsh BD (1998) On the interpretation of crystal size distributions in magmatic systems. J Petrol 39:553-599

Martel C (2012) Eruption dynamics inferred from microlite crystallization experiments: application to Plinian and dome-forming eruptions of Mt Pelée e (Martinique, Lesser Antilles. J Petrol 53:699-725

Mastrolorenzo G, Pappalardo L (2006) Magma degassing and crystallization processes during eruptions of high-risk Neapolitan-volcanoes: evidence of common equilibrium rising processes in alkaline magmas. Earth Planet Sci Lett 250:164-181
Melluso L, Morra V, Annamaria Perrotta A, Scarpati C, Adabbo M (1995) The eruption of the Breccia Museo (Campi Flegrei, Italy): fractional crystallization processes in a shallow, zoned magma chamber and implications for the eruptive dynamics. J Volc Geophys Res 68:325-339

Melnik O (2000) Dynamics of two-phase conduit flow of high-viscosity gas-saturated magma: large variations of sustained explosive eruption intensity. Bull Volcanol 62:153-170

Mormone A, Piochi M, Bellatreccia F, De Astis G, Moretti R, Ventura GD, Cavallo A, Mangiacapra A (2011) A $\mathrm{CO}_{2}$-rich magma source beneath the Phlegraean Volcanic District (Southern Italy): evidence from a melt inclusion study. Chem Geol 287:66-80

Mormone A, Piochi M, Troise C, De Natale G (2014) Il laboratorio di Diffrattometria a raggi $\mathrm{X}$ dell'Osservatorio Vesuviano (Istituto Nazionale di Geofisica e Vulcanologia, Napoli): identificazione e stima quantitativa delle fasi in campioni polverizzati. Rapporti tecnici INGV 279:7-21 ISSN 2039-7941

Parascandola A (1947) I fenomeni bradisismici del Serapeo di Pozzuoli. Genovese, Napoli

Piochi M, Mastrolorenzo G, Pappalardo L (2005) Magma ascent and eruptive processes from textural and compositional features of Monte Nuovo pyroclastic products, Campi Flegrei, Italy. Bull Volcanol 67:663-678

Piochi M, Polacci M, De Astis G, Zanetti A, Mangiacapra A, Vannucci R, Giordano D (2008) Texture and composition of pumices and scoriae from the Campi Flegrei caldera (Italy): implications on the dynamics of explosive eruptions. Geochem Geophys Geosyst 9 Q03013

Porter D, Easterling K (1997) Phase transformations in metals and alloys . Chapman and Hall, New York514 pp.

Putnis A (1992) Introduction to mineral sciences . Cambridge Univ. Press, New York457 pp.

Rosi M, Sbrana A (1987) Phlegrean fields . CNR Quaderni de "La Ricerca Scientifica” 9, Rome175 pp.

Rosi M, Sbrana A, Principe C (1983) The Phlegrean Fields: structural evolution, volcanic history and eruptive mechanism. J Volcanol Geotherm Res 17:273-288

Schneider CA, Rasband WS, Eliceiri KW (2012) NIH image to ImageJ: 25 years of image analysis. Nat Methods 9:671-675

Shea T, Hammer JE (2013) Kinetics of cooling- and decompressioninduced crystallization in hydrous mafic-intermediate magmas. $\mathrm{J}$ Volcanol Geotherm Res 260:127-145

Swanson SE (1977) Relation of nucleation and crystal-growth rate to the development of granitic textures. Am Mineral 62:966-978

Vona A, Romano C, Dingwell DB, Giordano D (2011) The rheology of crystal-bearing basaltic magmas from Stromboli and Etna. Geochim Cosmochim Acta 75:3214-3236 